\title{
A Generalized Overview of SARS-CoV-2: Where Does the Current Knowledge Stand?
}

\author{
Hiya Islam ${ }^{1}$, Ahsab Rahman ${ }^{1}$, Jaasia Masud ${ }^{1}$, Dipita Saha Shweta ${ }^{2}$, Yusha Araf ${ }^{3}$, Md. Asad Ullah ${ }^{4^{*}}$, \\ Syed Muktadir Al Sium ${ }^{5}$, Bishajit Sarkar ${ }^{4}$
}

\author{
${ }^{1}$ Biotechnology Program, Department of Mathematics and Natural Sciences, Brac University, Dhaka, Bangladesh \\ ${ }^{2}$ Microbiology Program, Department of Mathematics and Natural Sciences, Brac University, Dhaka, Bangladesh \\ ${ }^{3}$ Department of Genetic Engineering and Biotechnology, School of Life Sciences, Shahjalal University of Science and Technology, Sylhet, Bangladesh \\ ${ }^{4}$ Department of Biotechnology and Genetic Engineering, Faculty of Biological Sciences, Jahangirnagar University, Dhaka, Bangladesh \\ ${ }^{5}$ Child Health Research Foundation, Dhaka, Bangladesh \\ *Corresponding Author: ullah1194@gmail.com
}

Citation: Islam H, Rahman A, Masud J, Shweta DS, Araf Y, Ullah MA, Sium SMA, Sarkar B. A Generalized Overview of SARS-CoV-2: Where Does the Current Knowledge Stand?. Electron J Gen Med. 2020;17(6):em251. https://doi.org/10.29333/ejgm/8258

\section{ARTICLE INFO}

Received: 4 May. 2020

Accepted: 6 May. 2020

\begin{abstract}
The novel coronavirus known to have brought the world to a standstill is responsible for many deaths throughout the globe as of now. The causative agent (SARS-CoV-2) for coronavirus disease 2019 (COVID-19) has been recognized as a zoonotic transfer. Although, the medium of animal-human transmission is still unknown, bats maybe a potential reservoir of this novel strain. Due to its high rate of transmission the most favorable way of limiting the outbreak's extent is by early diagnosis followed by isolation of the infected individuals. So far, the most widely used diagnosis methods are RT-qPCR which detects specific sequences of the viral RNA. Some other methods include serological tests and the recently introduced CRISPR-CAS-12 based assays.

As of now, no specific therapeutic treatments are known for COVID-19 however the use of some broad-spectrum antiviral drugs and convalescent plasma therapy have demonstrated positive outcomes. Apart from these treatments, vaccine development for SARS-CoV-2 is also in progress by 17 known companies. This article provides a comprehensive insight on the recently emerged Severe Acute Respiratory Syndrome Coronavirus 2 (SARS-CoV2) including its origin, transmission mechanism, pathophysiology and updated treatment methods.
\end{abstract}

Keywords: COVID-19, SARS-CoV-2, origin, pathogenesis, diagnosis, treatment

\section{INTRODUCTION}

Being encountered by the coronavirus in its novel form yet again for the third time in the $21^{\text {st }}$ century brings it under the limelight once more. The coronaviruses belong to the order Nidovirales and the subfamily Orthocoronavirinae within the family Coronaviridae, the subfamilies can be further subdivided among 4 genera $\alpha, \beta, \gamma$ and $\delta(1,2)$. The $\alpha$ and $\beta$ are known to infect only mammals, while $\delta$ and $\gamma$ usually infect birds and fishes with a few exceptions of mammal hosts (2,3). Their infecting capacity of the hepatic, gastrointestinal, respiratory and central nervous system of a wide range of animal hosts (human, livestock, bat, birds, mouse and other wild animals) makes them a significant pathogen of interest $(4,5)$.

Coronaviruses are enveloped single stranded, positivesense RNA viruses with the largest known genome for RNA viruses, being around 26-32 kilobases in size with a 5'- cap structure and 3'- poly A tail $(1,6)$. The name 'Corona' has been derived from its morphological appearance, that includes spiked protrusions from its lipid membrane, giving it a structure similar to that of crown when viewed under electron microscope (corona in Latin) (7).
Human Corononaviruses (HCoVs) first described in 1965 in the name B814, when it was extracted from a patient's nasal release who was suffering from common cold (8). They are known to be associated with the infections of the respiratory and the gastrointestinal tract. To this date, seven strains of these HCoVs are known: 229E, OC43, NL63, HKU1 usually cause mild upper respiratory disorders in immunocompromised individuals with a few special cases of severe infections among newborns and elderly people; while SARS-CoV (Severe Acute Respiratory Syndrome related Coronavirus), MERS-CoV (Middle East Respiratory Syndrome related Coronavirus) and the 2019 novel Coronavirus(nCoV)/ Sars-Cov-2 are responsible for more critical lower respiratory tract conditions and SARS in humans (9-11). HCoVs are the causative agents for a broad range of pulmonary conditions ranging from mild, "self-limiting" diseases like the common cold to acute conditions like pneumonia and bronchitis, depending on the individual's immunity $(10,12)$.

Until the emergence of SARS-CoV and MERS-CoV human coronaviruses were not considered pathogenic and were known to circulate within humans without causing any major fatal diseases. With the onset of the SARS epidemic, coronaviruses started being evaluated as the "emerging pathogens". 
Initially observed in the Guangdong province of China, in February 2003, the initial cases of an unfamiliar respiratory illness were reported which was later found to have emerged in late $2002(13,14)$. It was known to be a result of recombination of bat SARS-CoVs possibly through masked palm civets (Paguma larvata) as the intermediate hosts prior to infecting humans, causing around 8000 cases of infections and more than 800 deaths worldwide with a $10 \%$ mortality rate (15-18).

Ten years after SARS-CoV (2012) another endemic broke out in Middle East, via a zoonotic transfer from dromedary camels as the intermediate host. MERS-CoV has a history of 2494 cases of infections and 858 fatalities worldwide including 38 deaths in South Korea followed by a single transmission case, with a comparatively greater fatality rate than SARS-CoV, being 37\% (19-21).

Both SARS-CoV and MERS-CoV has a history of initial zoonotic transfer followed by human-human transmission.

The most recent exposure of the human respiratory coronavirus, SARS-CoV-2 first identified in late December, 2019 in Wuhan China is the zoonotic causative agent for COVID-19, a respiratory condition resulting in severe pneumonia followed by ARDS (Acute Respiratory Distress syndrome) in more severe patients (1,22). COVID-19 may demonstrate itself as an asymptomatic carrier state, acute respiratory state and severe pneumonia and eventually cause death in immunocompromised patients. The rapid human-human transmission of the disease has been confirmed by the proof of clusters of infected family and medical personnel through nosocomial infection (23).

\section{ORIGIN, CHARACTERISTICS AND GENETICS OF SARS-COV-2}

The recently discovered novel strain of the Human Coronavirus named SARS-CoV-2 is the causative agent for the respiratory illness COVID-19 (termed by WHO on Feb 11, 2020) that has been declared as the sixth "Public Health Emergency of International Concern" since the onset of H1N1 (2009), Polio (2014), Ebola in West Africa (2014), Zika (2016), Ebola in Democratic Republic of Congo (2019) (24).

SARS-CoV-2 (belonging to the genus of betacoronavirus and subgenus sarbecoronavirus) has a typical genomic structure like most coronaviruses in that $2 / 3^{\text {rd }}$ of their genomic matter code for 16 non-structural proteins (nsps) associated with genome transcription and replication (with the exception being Gammacoronavirus which does not have the $1^{\text {st }} \mathrm{nsp}$ ) while the remaining $1 / 3^{\text {rd }}$ region in proximity to the $3^{\prime}$ terminal region codes for 4 essential structural proteins: Spike (S), Envelope (E), Nucleocapsid (N) and Membrane (M) proteins, along with some other special structural and accessory proteins. The structural proteins responsible for the infectivity and "assembly" of the viruses among the different CoVs are known to vary among themselves with $43 \%$ sequence identity, in contrary to the non-structural proteins that are more similar with $58 \%$ sequence identity (7). The functions of the 4 essential structural proteins are briefly described as follows (Figure 1):

- Spike (S) protein are associated with the virion attachment to the host cell receptors by initiating the fusion of the cell membrane and viral envelope, the configuration of $\mathrm{S}$ glycoprotein determines the host range. It is also targeted site for antibodies $(25,26)$.

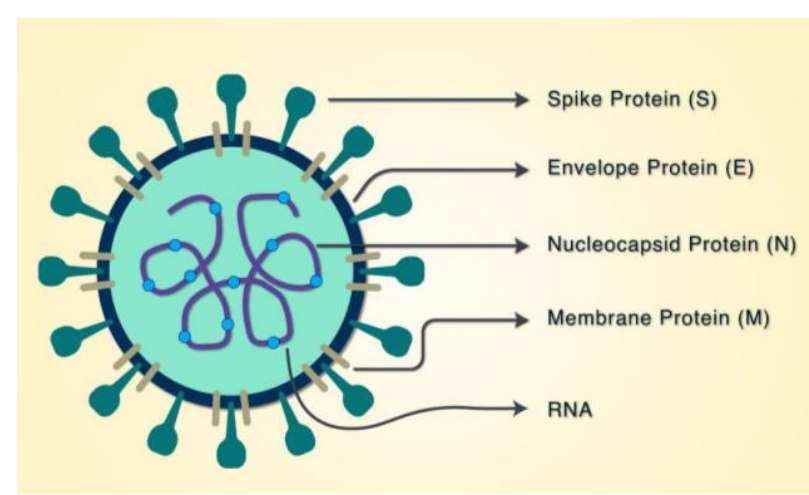

Figure 1. Typical Structure of SARS-CoV-2. The coronavirus spike (S) protein mediates membrane fusion by binding to cellular receptors. The figure was created using "BioRender.com" template and exported under the terms of premium subscription.

- Membrane protein (M) maintains the virions shape and structure it also attaches itself to the nucleocapsid $(27,28)$.

- Envelope $(E)$ is essentially associated with the release of the replicated virus and its assembly within the host cells $(29,30)$.

Initially few patients were hospitalized with then unclassified pneumonic conditions in late December 2019, all with a history of exposure to a seafood and wet animal wholesale market in Wuhan province, China (31). Within the period between December 18 to December 29, five more patients were diagnosed with Acute Respiratory Distress Syndrome (ARDS) leading to the death of one (32). It was later discovered by CDC (Center for Disease Control) after subsequent analysis of the infected individual's respiratory samples that these conditions were due to a novel coronavirus strain which was temporarily named $2019 \mathrm{nCoV}$ by WHO on $12^{\text {th }}$ Jan 2020 and later changed to SARS-CoV-2 based on its phylogenetic and taxonomic grounds, by the International Committee on Taxonomy of virus (33). Next generation sequence results from cultured virus samples obtained from 9 ( 8 of them had direct exposure to the wet market while 1 did not) patients affected during the early phase of the outbreak lead to detailed knowledge about the 2019 nCoV genomic characteristics including its similarities and differences to the other known coronaviruses (32). The complete viral genome was obtained from a patient on January 5, 2020 by next generation meta-transcriptomic sequencing (34).

Comparative genomic analysis via Blastn lead to the findings that the virus is closely to the novel strain were bat-SLCoVZXC45, with a sequence identity of $87.99 \%$ and bat-SLCoVZX21 with a sequence identity of $87.23 \%$, this leaves possibilities of SARS-CoV-2 having originated from bats within the market region (32). SARS-CoV-2 is 79\% similar to SARS-CoV on the nucleotide level, while being $72 \%$ similar in their spike protein sequences. The Receptor Binding Domains of SARSCoV-2 are ideally structured for binding to the human Angiotensin Converting Enzyme 2 (ACE2) receptor which is the same receptor recognized by SARS-CoV, however 5 out 6 of these residues in the RBD seem to differ between them, the high affinity towards the ACE2 receptor may been acquired as a result of natural selection within a human or a human like ACE2 that allows binding (35). The most closely related virus to SARS-CoV-2 is RaTG13 derived from Rhinolophus affinis bat 
showing $96 \%$ identical overall to SARS-CoV2, however the spikes differ in the receptor binding domains being only $85 \%$ similar where only one of the six amino acid residues match (34). Malayalan Pangolins (Manis Javanica) too show similarity with SARS-CoV-2 (91.02\% identity at the whole genome level), demonstrating strong uniformity in the RBD region including all six of the RBD residues, suggesting them to be the potential intermediate host, however there may be multiple intermediate hosts (36). Thus, incapability to identify the intermediate host is curtailing the chances of gaining deeper insights about the spillover of the virus into the human population, which in turn is also limiting the determination of the containment of the virus.

Although bats are thought to be the potential reservoirs hosts of this novel coronavirus since they have been playing pivotal roles in transmitting other viruses like Ebola and Nipah, however this hypothesis must be backed by further confirmations (34).

SARS-CoV-2 has been proved to be more infectious than both SARS-CoV and MERS-CoV and as of $16^{\text {th }}$ April, 2020, there are 1,995,983 confirmed global cases with 131,037 deaths across 213 countries and territories and 2 international conveyances (37).

Much of the existing treatment methods have resulted out from understanding of the previous 2 outbreaks, particularly the SARS-CoV outbreak which shares similarities with the novel strain of the Coronavirus. However, in order to generate treatments with high efficacy, the unique features of SARSCoV-2 must be understood to a greater extent, specially its spike protein. Beside these, different serotypes are being identified in different countries with slight variation which may responsible to different host response, pathogenesis, symptoms in different regions.

\section{TRANSMISSION}

By the end of 2019, Wuhan, the capital of China's Hubei province encountered an outbreak of a novel coronavirus, which has taken the lives of more than eighteen hundred people in the first seven weeks. The phenomenon was first informed to the World Health Organisation (WHO) by the Chinese government when they observed several cases of unusual pneumonia $(38,39)$.

The disease was initially thought to be generated from the Huanan seafood market of Wuhan and spread rapidly from there (39). However, several researches have suggested that bats which are not available in the Huanan seafood market might be the potential reservoir of SARS-CoV-2. That only leads to two possible explanations: 1) the disease did not generate from the Huanan seafood market, or 2) an intermediate host was involved in spreading the disease from the Huanan seafood market. If we consider that bats are indeed the reason behind the origin of this disease and it was indeed initiated from the Huanan seafood market, then that only leaves us with the possibility of an intermediate host. Through phylogenetic analysis and protein sequence alignment, researchers have shown that the involvement of an intermediate host, such as turtles, pangolin etc. is more than possible (39-41).

Study shows that COVID-19 primarily spreads through the respiratory tract, droplets, respiratory secretions, and direct contact (42). The virus uses nose and mouth as the entryway and then searches for a 'host cell' in the respiratory system. Nearby cells are infected when the host cell bursts (43). There is a possibility that a person may get infected by "touching a surface or object that has the virus on it", and then touching their nose, mouth or eyes. As a result, the CDC recommends keeping the hands clean by washing with soap or using alcoholbased hand rub (44). Several researches also explore the possibility of vertical transmission where women infected with coronavirus during pregnancy can transfer the disease to infants. A study was conducted of 33 women who were infected by the virus during their pregnancy in China. They gave birth to babies and three of the infants were infected among them. Two of the babies were delivered at full term and they experienced fever and excessive vomiting upon their birth. They also showed signs of pneumonia, and tested positive for the COVID19. One of the babies was delivered nine weeks early due to the mother facing several complications including pneumonia. The health problems of that baby might be caused by premature birth rather than COVID-19 (45). However, a study of 31 pregnant women infected with coronavirus shows that vertical transmission is not evident. While two mothers died due to respiratory complications caused by COVID-19, the infants remained healthy (46). Recently, it has been reported that a tiger in the Bronx zoo was tested positive for coronavirus. The 4-year-old tiger named Nadia was experiencing dry cough, and it was tested for the virus on April 2 when its twin sister, Azul, two Amur tigers, and three African lions developed a dry cough as well. Zoo officials believed that Nadia was infected by a zookeeper; however, ongoing researches are exploring new possibilities $(47,48)$.

Upon its generation, the virus has since infected 2,261,397 individuals across 210 countries and territories till the date of this writing. Amongst them, 154,726 have died and 579,187 have recovered (49). The rate of transmission of SARS-CoV-2 is far greater than that of SARS-CoV, an epidemic that affected 26 countries and resulted in more than 8000 cases in 2003 . The reason behind the higher transmission rate of SARS-CoV-2 includes the genetic recombination event at spike protein in the RBD (Receptor Binding Domain) region of SARS-CoV-2 $(50,51)$.

On January 20, the US saw its first case when the virus was found in a 35-year-old man who had just returned from Wuhan 5 days earlier (52).

Within the last week of January, Europe also saw its first case when an infected patient was confirmed in Bordeaux on January 24 (53). Australia first encountered the virus on January 25 when a returning man from Wuhan tested positive for coronavirus (54).

WHO officially declared the COVID-19 phenomenon a Public Health Emergency of International Concern (PHEIC) on January 12 and a pandemic on 11 March after the widespread of the virus throughout the world (37).

The high contagious nature of the virus makes it difficult to prevent the rapid transmission and the limited understanding about its host again imposes additional challenges which subject more research to be carried out and more about the mode of transmission is yet to be discovered. 


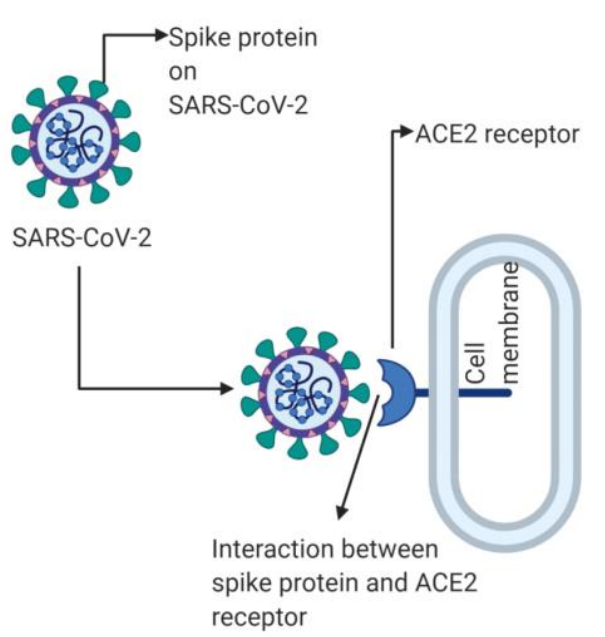

Figure 2. Interaction of spike protein of SARS-CoV-2 with ACE2 receptor during entry inside cell. The picture was created from BioRender and downloaded with the premium subscription

\section{PATHOGENESIS OF SARS-COV-2 INFECTION}

In order to infect a host cell, gaining entry into individual human cell is a must. The virus then utilizes these cells' machinery to produce copies of themselves which then ultimately spreads out to new cells (55). A research study mentioned about a molecular key on the novel coronavirus which provides the virus with an entryway to the cell. The molecular key is termed as Spike protein or S-protein (56). A research team in China led by Qiang Zhou in China revealed that the spike protein interacts with a "receptor on respiratory cells called angiotensin-converting enzyme 2" (Figure 2) (57). The spike protein has a furin cleavage site. Furin is present in the lungs, liver, and small intestines of human which basically indicate that the virus may infect several body organs (58). Some other groups also regarded the "activation site" as an efficient way of spreading between human, which however was disapproved by some researchers (59).

The interaction between spike protein and ACE2 receptors enables the entry of the virus in the human cell. Once inside, the virus infects healthy cells $(60,61)$.

In brief, the replication begins through the binding and entry of coronavirus into the host cell with the help of endocytosis process or membrane fusion. Following its entry into the host cell, the coronavirus releases its viral genome which then undergoes a process of translation. After the viral polymerase protein is translated, RNA replication occurs. Then it is followed up with sub genomic transcription. Structural protein of the virus is then translated. The structural proteins undergo combination with nucleocapsid. Finally, mature virion is formed and released through exocytosis mechanism. (Figure 3) (62).

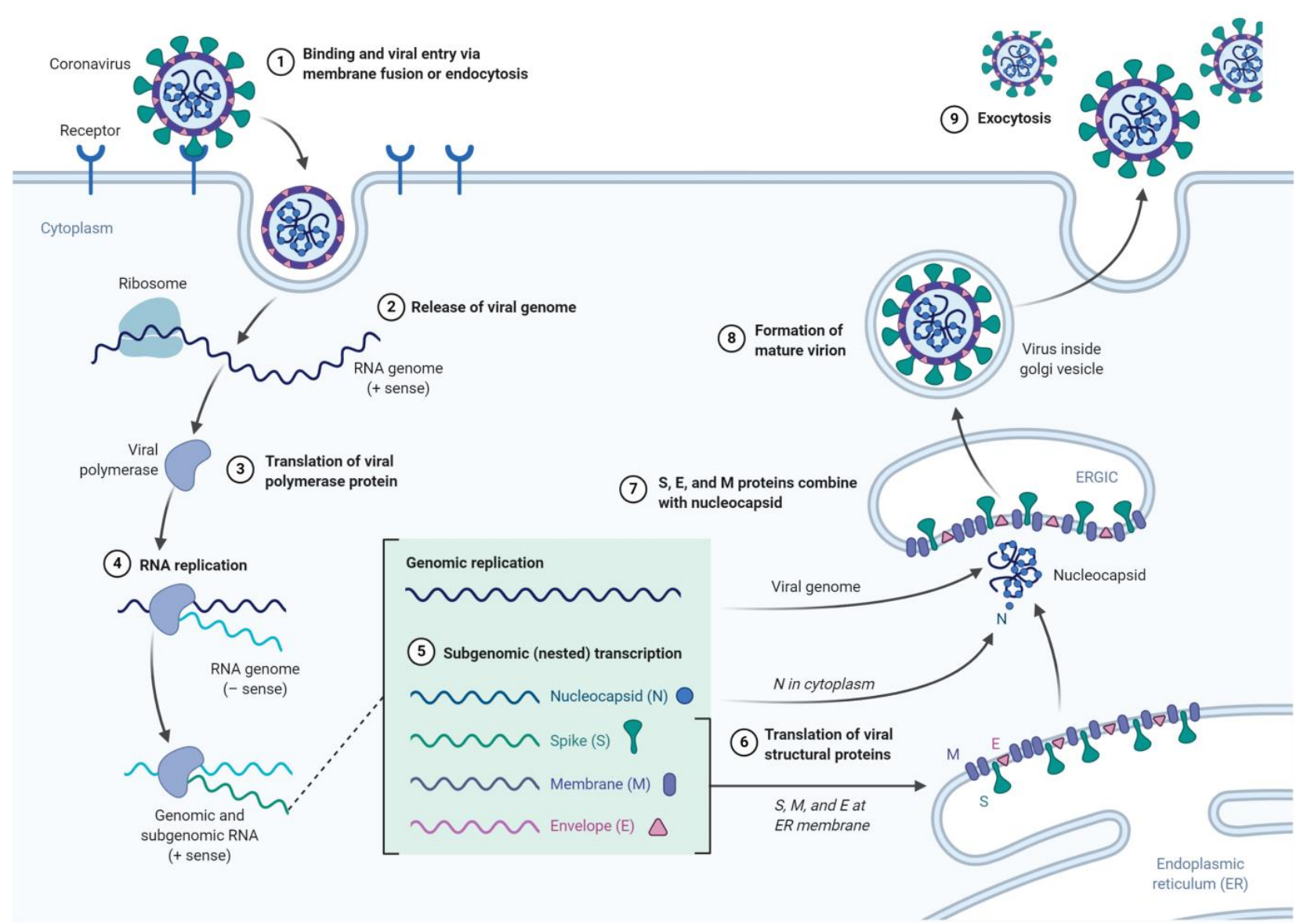

Figure 3. The SARS-CoV-2 replication cycle in mediating the viral pathogenensis. Virus enters the cell after binding to the cell surface receptor of host cell and then replicates and transcribes viral genome and proteins, respectively. After virus assembly, they lyse the cells and get outside of the infected cell and continue infection of new healthy cell. The picture was created from BioRender and downloaded with the premium subscription. 
Table 1. Symptoms associated with SARS-CoV-2 infection

\begin{tabular}{ccc}
\hline Symptoms & Percentage & References \\
\hline Fever & $83-99 \%$ & \\
Cough & $59-82 \%$ & \\
Fatigue & $44-70 \%$ & $(22,65-71)$ \\
Anorexia & $40-84 \%$ & \\
Shortness of breath & $31-40 \%$ & \\
Sputum production & $28-33 \%$ & \\
Myalgia & $11-35 \%$ & \\
\hline
\end{tabular}

When the virus invades the respiratory tract, the lungs become inflamed. As a result, a person may experience some breathing difficulty. This may also result in pneumonia which could be fatal. In severe cases, this may lead to Acute Respiratory Distress Syndrome (ARDS) which may enhance the breathing difficulty, or result in rapid heart rate, sweating and dizziness. The patient's alveolar blood vessels and tissues might also get damaged making it even harder to breathe. Through the collection of fluids in the lungs, oxygen will be carried less to the blood. As a result, enough oxygen will not be supplied to other body organs leading slowly to organ failure $(61,63)$.

\section{SYMPTOMS AND CLINICAL PRESENTATION}

As mentioned earlier, COVID-19 can be spread through respiratory tract, droplets, respiratory secretions and direct contact. Upon its exposure, the person infected with the novel virus may show some symptoms within 2-14 days (incubation period). Centers for Disease Control and Prevention (CDC) mentions some of the signs and symptoms that may appear in an infected patient which include fever, cough and shortness of breath. CDC also points out a few emergency warning signs which will help to determine when to see a doctor. The signs include breathing difficulty, persistent pressure on the chest, inability to be aroused etc. $(44,64)$.

There has been a little dispute regarding the incubation period of COVID-19. According to the CDC, the incubation period may "extend to 14 days, with a median time of 4-5 days from exposure to symptoms onset". The source also mentioned that $97.5 \%$ of the people may develop the symptoms within 11.5 days. While the signs and symptoms may vary from person-to-person, CDC has altogether shown a variety of symptoms that might be observed in an infected patient over the course of the disease (Table 1). However, the incubation period is between 2 to 10 days according to WHO (72). China's National Health Commission (NHC) reported an incubation period for 10 to 14 days (73).

\section{Prognosis: A Day-to-day Breakdown of Coronavirus Infection and COVID-19 Development}

Following is a day-to-day breakdown of the novel COVID-19 symptoms and a brief view of how the disease progresses:

Day 1-3: The patient may experience fever (temperature $>100^{\circ} \mathrm{F}$ ) at the initial stage. Prolonged fatigue and dry cough might be evident. Mild muscle pain and breathing difficulty might also be an issue. The patient may also face sore throat, blocked nose, or runny nose although these are less common $(43,74)$.

Day 4-7: This is the stage where the symptoms generally escalate and breathing difficulty becomes a major issue, especially for elderly people. Patients with a preexisting health
Table 2. Clinical courses of COVID-19

\begin{tabular}{clll}
\hline Time Interval & \multicolumn{1}{c}{ Clinical Course } & References \\
\hline & - & Fever (temperature $\left.>100^{\circ}\right)$ & \\
& - Prolonged fatigue & \\
& - Dry cough & $(43,74)$ \\
Day 1-3 & Mild muscle pain & \\
& - Breathing difficulty & \\
& - Sore throat & \\
\hline Day 4-7 & - Blocked nose & Excessive difficulty in breathing & $(43,75)$ \\
\hline \multirow{3}{*}{ Day 8-12 } & - ARDS & $(43,74,75)$ \\
& - Abdominal pain & \\
\hline
\end{tabular}

condition are also at high risk. This is the point when the patient must be admitted to a hospital $(43,75)$.

Day 8-12: At this stage, the patients generally tend to develop symptoms of ARDS, a hazardous condition when the vital organs of the body cannot receive sufficient amount of oxygen. ARDS is often very fatal, and the patients are shifted to the ICU at this point. Abdominal pain and appetite loss can also be seen in the patients at this stage (Table 2) $(43,74,75)$.

Although a number of common symptoms is considered to be associated to the preliminary phases of the infection but ranges of different symptoms are being recorded frequently in different region which might be due to the mutation of the viral strain.

\section{PREVENTIVE MEASURES}

The SARS-CoV-2 can be transmitted via contact, droplets and fomites. In order to avoid spreading by droplets or contact, US Centers for Disease Control and Prevention (CDC) recommends good hand hygiene by washing hands with soap or alcohol-based sanitizers and social distancing by maintaining at least 1 meter gap. And as the virus can persist on objects, mindful cleaning with soap and water of frequently touched surfaces such as door knobs, tables or light switches, is another vital practice to avoid getting infected. WHO advises symptomatic people to be isolated in one room with a separate bathroom and avoid sharing items with others $(76,77)$. The interim guidance on infection prevention and control (IPC) by WHO has clearly set instructions for healthcare workers (HCWs) or managers to ensure clinical triage, early identification and control of source, proper use and adequate supply of Personal Protective Equipment (PPE), thorough cleaning of the environment and effective training of the HCWs. Collection of specimen for laboratory investigation must be done by personnel who are trained in safe handling of the samples; and in laboratories, biosafety practices are to be maintained. The components of PPE are face masks, face shields, gloves, eyeprotective goggles and polyethylene coated gowns. The IPC guidelines also expect all the health facilities to educate caregivers and patients' families on recognizing early symptoms and basic precautions according their schemes and methods. Airborne precautions must be taken into account which holds the possibility of contamination via suspended infectious agents in the air; such as use of N95 masks in perioperative environment, education on seal checks of respirators and directing a patient's tube to appropriate Breathing System Filters (BSF) after endotracheal intubation $(78,79)$. Safe management of corpses of people who have died of suspected or confirmed COVID-19 is important; because the 
virus can live inside the lungs or other organs of the body although there is no evidence of getting infected from the dead body yet. The burial team dealing with the body must use appropriate PPE, wash hands before and after handling the body and make sure to disinfect the surfaces where the body was kept and any autopsy items: with $0.1 \%$ Sodium hypochlorite or $70 \%$ ethanol. Family members are not allowed to touch or kiss the body; they may only see the body after it has been prepared for burial with certain standard precautions. Overcrowding should be avoided by restricting the number of participants and people with respiratory difficulties are encouraged to attend only by wearing masks (80).

In a time like this when the pandemic is spreading like fire and the cure is yet to be confirmed and produced, prevention is the only retaliation in hand. But these standards mentioned above are not expected to be maintained in all countries. There are certain aspects which play a role; such as the socioeconomic condition of country, we must wonder how many countries can actually afford lockdown in order to maintain social distancing. Secondly, scientific knowledge about the infection and thus awareness regarding controlling the pandemic is not uniform among the regions that are suffering which will hamper the implementation of the preventive measures included. Therefore, all the affected countries' progress in minimizing the spread of the disease is not similar.

\section{INCUBATION PERIOD}

The incubation period is the first stage in the progression of a disease; defined as the time between the initial exposure to a microorganism and the development of the symptoms. In this stage, the replication of the pathogen begins so its duration may depend on the type of pathogen, its virulence, host's defense and site of infection. This particular period of any disease is crucial as the person does not realize being infected due to the lack of symptoms but still can spread the pathogen to others which is known as pre-symptomatic transmission (81). Total 88 COVID-19 cases confirmed from 20 to 28 January were gathered from premises outside Wuhan; and were used in an investigation to confirm the incubation period to be 6.4 days. But only few number of cases used in this study which was not enough to find out if the incubation period differs with age and sex. Also, the cases reported were from regions with proper health management and awareness so it has been suggested in the paper that more research is required regarding cases with mild symptoms, morbidity factors and older age group (82). In order to determine the geographic spread of the virus, a study was conducted using cases from both outside Wuhan and residents of Wuhan. The results showed the incubation period to be 5.0 days for 52 cases from residents outside Wuhan and 5.6 days for 158 cases who lived in Wuhan (83). Another study on $181(60 \%$ male, median age: 44.5 years) confirmed cases of the time period from 4-24 February outside of Hubei province in China, among which 161 cases had residence or had a travel history to Wuhan; the rest of them however were investigated to be in contact with the infected ones. Statistical analysis of these data was done using log-normal model which shows estimated median incubation period to be 5.1 days and estimated mean to be 5.5 days. In addition to that, less than $2.5 \%$ of infected people will show symptoms within 2.2 days of exposure and symptoms onset for
$97.5 \%$ will be within 11.5 days (84). Both large health organizations $\mathrm{CDC}$ and $\mathrm{WHO}$ have also advised an active monitoring period to be 14 days; which can be supported by the findings of these researchers $(85,86)$. The value of the mean incubation period differs from one study to another mainly because of the different cities in China used for collecting the cases. Cases in the studies mentioned were taken from Wuhan or other cities outside of Wuhan; so the testing records, healthcare management and awareness regarding the disease may vary from city to city. Moreover, cases with mild symptoms were not included in any of the studies so the finding values of the mean incubation period may fluctuate with further research.

\section{REPRODUCTION NUMBER}

The virulence of a disease depends on the reproduction number of the virus. Effective reproductive number $(R)$ is termed as the average number of secondary cases infected from a single infective in a population that consists of both immunized (vaccinated or primarily infected) and susceptible hosts. This value is used to deduce the preventive measures taken in order to limit the spread as its magnitude depends on those measures. The value of $R$ less than 1 is an indication that prevention steps taken to control the outbreak are being effective and there is a decrease in the number of cases. When the value of $\mathrm{R}$ reaches 1 it refers to an epidemic and $R>1$ means that the number of cases is amplifying (87-89). Basic reproduction number $\left(R_{0}\right)$ is also referred to the number of new cases of infection generated from one case but in a population that includes susceptible hosts only. It depends on the duration of infectious or latent period, contacts per unit of time and chances of transmitting the disease per contact $(88,90)$. It is crucial to maintain $R_{o}<1$ so that the threshold for herd immunity is overcome and the infection is successfully eliminated by mass immunization $(88,91)$. A number of SARSCoV-2 cases from January 10 to 24 January, 2020 mainland China was collected for a study to initially estimate the $R_{o}$ of the novel corona virus and the results was in a range of 2.24-3.58. But the serial interval ( $\mathrm{SI}$ ) of novel corona virus was not known yet and the analysis was done based on the SI of SARS and MERS. Serial Interval is the duration recorded from the appearance of symptoms of the first case to the symptom onset of a second case infected by the first case; calculated by collecting vast amount of data on the succession of the spread of infection and thus determines the result of $R_{0}(92,93)$. Another study was carried out using data of cases from Dec 13, 2019 to Jan 28,2020 which concludes $R_{o}$ to be approximately 2.68 and epidemic doubling time to be 6.4 days. The researchers used the estimated SI of SARS and Markov Chain Monte Carlo methods to estimate the $R_{o}$. They also inferred their findings as an indication that there is exponential growth of the outbreak in many cities of China (94). Another experiment included results of an analysis done on time-series data of novel coronavirus-infected pneumonia-coronavirus (NCIP$\mathrm{CoV}$ ) till January 22 and the basic reproductive number was calculated to be 2.2. The SI was analyzed to be 7.5 days which was considered in this statistical analysis. The findings of the study helped the investigators to confirm human-to-human transmission and estimate the severity of the infection but it is also mentioned that the study did not include cases with "mild infections" which has fluctuated the results $(95,96)$. A recent study on April showed the median basic reproduction number 
Table 3. Comparison of SARS-CoV-2 with MERS-CoV, SARS-CoV and Ebola regarding incubation period and basic reproductive number

\begin{tabular}{|c|c|c|c|c|c|c|}
\hline Viruses & $\begin{array}{l}\text { Year and place of } \\
\text { Identification }\end{array}$ & $\begin{array}{l}\text { Mean Incubation } \\
\text { Period }\end{array}$ & $\begin{array}{c}\text { Active } \\
\text { Monitoring } \\
\text { Period by WHO }\end{array}$ & $\begin{array}{c}\text { Basic Reproductive } \\
\text { Number }\left(R_{\mathbf{0}}\right) \text { in early stage }\end{array}$ & $\begin{array}{c}\text { Number of } \\
\text { countries and } \\
\text { territories infected }\end{array}$ & Reference \\
\hline MERS-CoV & 2012 in Saudi Arabia & 5-7 days & 14 days & $\begin{array}{l}\text { - } 0.45-0.98 \text { in Saudi Arabia } \\
\text { - } 2.5-8.09 \text { in South Korea }\end{array}$ & 27 & $(102-112)$ \\
\hline SARS-CoV & 2002 in Southern China & 4 days & 10 days & 2.9 & 26 & $(113-116)$ \\
\hline SARS-CoV-2 & 2019 in Wuhan & 5.5 days & 14 days & $2-2.5 \backslash 5.8$ & 210 & $\begin{array}{c}(49,84,85 \\
97,100,117)\end{array}$ \\
\hline Ebola & $\begin{array}{c}1976 \text { in Sudan and } \\
\text { Democratic Republic of } \\
\text { Congo }\end{array}$ & 2-21 days & 21 days & $\begin{array}{l}\text { - } 1.51 \text { in Guinea } \\
\text { - } 2.53 \text { in Sierra Leone } \\
\text { - } 1.59 \text { in Liberia }\end{array}$ & 10 & [118]-[120] \\
\hline
\end{tabular}

to be 5.8; considering SI equals to 7-8 days (97). The data of serial interval used was collected from past analysis, i.e. 7.5 days (95). However, the value of $R_{0}$ will be lesser if the value of $\mathrm{SI}$ is shorter; but SI value to be less than 6 days is implausible because immediate hospitalization of patients is not always feasible (97). There is a correlation between the serial interval and the time taken for an infective to be isolated after showing symptoms; thus more the delay to be hospitalized, greater the $\mathrm{SI}$ value is (98). A group of analyzers has gathered all the values of the basic reproduction number from various studies and calculated the mean $R_{0}$ to be 3.28 and median to be 2.79 (99). Lastly, according to a report published by WHO, the estimation of $R_{0}$ was calculated to be 2-2.5 (100).

Table 3 compares SARS-CoV-2 with other highly infectious viruses: MERS-CoV, SARS-CoV and Ebola in terms of their mean incubation period and reproduction number. It can be deduced that the mean $R_{0}$ for COVID-19 falls in the range of estimated $R_{0}$ value of SARS. This was bound to happen as both viruses are similar and was identified within the same country. But it can be taken under consideration that COVID-19 is more contagious because it has spread to more countries in a short time compared to SARS and MERS $(101,102)$. Ebola seems to be less transmissible but has the highest mean for incubation period (Table 3 ).

\section{DIAGNOSIS}

Efficient diagnostic testing for COVID-19 has a vital role to play in minimizing the spread of outbreak as verified drug therapy or vaccination is yet to be discovered (121). Early testing will make sure of fast hospitalization or isolation of the identified cases; preventing further spread of the infection resulting in lowering the probability of community transmission (122). A study on the effects of identification of cases and isolation shows that the percentage of contact tracing is directly proportional to the basic reproduction number $\left(R_{o}\right)$. For example, $R_{0}$ value of 1.5 requires tracing of $50 \%$ of cases to control the transmission where as $70 \%$ of contact tracing is essential in case of $R_{0}$ of 2.5 or more (123). People should only get tested if they show characteristic symptoms of COVID-19 or have been in contact with an infected person. There are different diagnosis techniques available which vary on the basis of diagnosis, types of sample used, specificity and sensitivity of the diagnosis methods etc.

\section{Real-time Quantitative Polymerase Chain Reaction (RT- qPCR)}

This is commonly used to detect viruses from respiratory secretions in acute respiratory infection. The sample for testing is collected by swabbing the nasopharyngeal with a cotton swab or the sputum is obtained by coughing. Viral transport media is added and then RNA is extracted using extraction kits $(124,125)$. Amplification of specific gene sequence is carried out by putting the mixture of the extracted RNA, reaction buffer, reverse transcriptase enzyme, Taq Polymerase, primers and probe; in a thermal cycler. In thermal cycling, different temperature and time period are maintained for the activity of reverse transcriptase enzyme $\left(55^{\circ} \mathrm{C}\right.$ for $\left.10 \mathrm{~min}\right)$, denaturation, annealing and extension (126). To detect different gene sequences of the virus, specific primers and probes are used that are complementary to the sequence. Thus, different kits are used to target different sequence such as QuantiNova SYBR Green RT-PCR Kit (Qiagen) for S gene, TaqMan-based fluorescence signal to identify the genes ORF1B and $N$ separately. However, this technique has drawbacks like takes more time to give results, chances of infection from the samples collected, high rate of false positive results and at times clumsy procedures of mixing solutions $(124,127)$. A study was conducted in order to compare the positive ratio of other types of sample such as blood, urine and stool with oropharyngeal swab. Even though negative results were found using urine and blood samples; surprisingly, 8 out of 9 stool samples of confirmed infected cases gave positive results despite of no symptoms for diarrhea. This indicates possibilities of another mode of transmission of the disease which is through feces (128). Another process to detect the viral RNA is high-throughput sequencing (HTS) of the whole genome. But as it is expensive and requires sophisticated equipments, RT-qPCR is a better option when it comes to availability and frequent testing. RT-qPCR also has high sensitivity (50\%-70\%) for the infection although it is affected by the protocol used and the specimen collected (129).

\section{Serological Tests}

The main principle of serologic tests is the identification of virus specific antibody complex formed as a result of the infected person's immune response. Types of serologic tests include: Rapid Diagnostic Test (RDT), Enzyme -linked immunosorbent assay (ELISA) and Neutralization assay (Table 4) (130).

An investigation using combined IgM-IgG antibody ELISA kits based on both nucleocapsid protein $(\mathrm{rN})$ and spike protein (rS) was conducted on 214 patients. The results showed $80.4 \%$ positive rate for $\mathrm{rN}$ protein and $82.2 \%$ for $\mathrm{rS}$ protein for either or both of the antibodies. It was concluded with ELISA technique to be highly sensitive for diagnosis of COVID-19 by using serum samples from patients 10 days after post-disease onset (131). The sensitivity and specificity of the antibodyantigen test was analyzed using blood samples from 525 cases 
Table 4. Differences between the three types of serologic tests regarding their type, type of sample required, amount of time needed and what it detected for results

\begin{tabular}{ccccc}
\hline Name of the test & Type of test & Test Samples & Time & Results \\
\hline Rapid Diagnostic Test (RDT) & Qualitative only & Blood, saliva and nasal swab & $10-30$ minutes & Presence of antibodies \\
\hline ELISA & $\begin{array}{c}\text { Qualitative and } \\
\text { Quantitative }\end{array}$ & $\begin{array}{c}\text { Whole blood, plasma and } \\
\text { serum }\end{array}$ & 1-5 hours & Presence of antibodies \\
\hline Neutralization Assay & $\begin{array}{c}\text { Qualitative and } \\
\text { Quantitative }\end{array}$ & Blood, serum and plasma & 3-5 days & $\begin{array}{c}\text { Presence of active antibodies } \\
\text { and memory cells }\end{array}$ \\
\hline
\end{tabular}

and the results showed to be $88.66 \%$ and $90.63 \%$ for sensitivity and specificity respectively. The study also used various type of blood sample: vein blood, plasma and fingerstick blood (132). Serology based tests can be used in large-scale, easy sample collection as antibodies are abundant in the blood serum, easy storage of sample as antibodies are more stable than RNA and antibodies are available for longer period in the blood unlike virus in sputum sample. But one limitation is that detection of antibodies may not be possible after at least 3 days of symptom development due to the slow immune response to the virus (133).

\section{Computed Tomography Scan (CT scan)}

There are high chances of infected persons missing out if CT scan is not done along with nucleic acid detection, according to this study. There are high chances of Highresolution CT scan of chest not only helps with early diagnosis but also gives an idea about the severity of the infection. HRCT has benefits like high sensitivity and easy to use. The features of the images mostly of the patients are diversified and thus radiologists must be well-informed about the characteristic changes due to the virus $(128,134)$. Based on several studies, chest imaging features have been found to be similar to SARS $\mathrm{COV}$ and MERS-CoV. Some of these features analyzed in the studies were mostly the "presence of ground-glass opacities", "presence of pleural effusion", "presence of consolidation" etc. (135-137). Common characteristic of the CT scan image of COVID-19 infected patient are bilateral pulmonary parenchymal ground-glass and consolidative pulmonary opacities; but there was an absence of other abnormal features like lung cavitation, discrete pulmonary nodules, pleural effusions, and lymphadenopathy (138). CT-Scan uses X-ray beams that bombards with the organs and bones inside the body to give images from various angles ultimately combined together to demonstrate a cross-sectional structure of the body part $(139,140)$. Drawbacks of this method are other viral pneumonia may show similar abnormalities and any malfunction of the machine may compromise the results.

\section{CRISPR-CAS12-based Assay}

Considering the lengthiness of the RT-qPCR method and dependency on the generation of antibodies in case of serologic tests, more rapid and accurate diagnostic method has been developed which is the CRISPR-CAS12-based assay (141). CRISPR technology is an effective tool to operate genomic modifications for correcting defective genes and putting a stop to the spread of a disease. "CRISPR" stands for clustered regularly interspaced short palindromic repeats; combined with CRISPR-associated (Cas) proteins; it is a defense system used by bacteria and archaea to destroy foreign nucleic acid during a viral invasion $(142,143)$. CRISPRCas12a enzymes are RNA-mediated cutting enzymes that cleave double-stranded DNA and can also make targeted nonspecific single-stranded cuts. CRISPR based DETECTR (DNA endonuclease-targeted CRISPR trans reporter) assay is a method which uses this ssDNAase activity of Cas12a combined with isothermal amplification using loop-mediated amplification for the extraction of RNA from samples $(144,145)$. It takes about 30 minutes to give results using DETECTR platform using a lateral flow strip format and specific sets of gRNA (guide RNA) are used to whether identify SARS-CoV-2 or any strain of coronavirus such as SARS-CoV or bat. The detection of the targeted sequence depends on the design of the primers, $C D C$ and $\mathrm{WHO}$ guidelines suggest it to be specific to $\mathrm{E}$ (Envelop) and N (Nucleocapsid) genes $(141,146,147)$. The optimized conditions for this assay is $62^{\circ} \mathrm{C}$ for $20-30 \mathrm{~min}$ during isothermal amplification (RT-LAMP) and $37^{\circ} \mathrm{C}$ for $10 \mathrm{~min}$ for Cas 12 detection. According to the guidelines of current US FDA EUA, the test is assumed to be positive if anyone of the $E$ or $\mathrm{N}$ genes is detected and is definitely positive in case both genes are detected. Results displayed on the lateral flow strips are brought by the use of a FAM-biotin reporter molecule; cleaving of the molecule by Cas 12 creates a signal on the second detection line (test line) and negative results will be interpreted by a signal on the first detection line (control line) generated by uncleaved reporter molecules (141-149). Another protocol has been shared by a group of researchers which includes the CRISPR-based SHERLOCK (Specific High Sensitivity Enzymatic Reporter UnLocking) technique to detect the viral genome. This process requires a total of an hour for the isothermal amplification of the extracted RNA from samples, Cas 13 activity for the detection of viral RNA sequence and visualization of detection using a paper dipstick. However, the study was not done using patient's samples so it is not wellestablished yet (150).

All these methods have their characteristic benefits and drawbacks. But their usage may vary from country to country although most countries are using the RT-PCR method. The preference may depend on the country's budget, methods like high throughput sequencing and CRISPR-CAS may be too expensive in a time when frequent testing is required. But then again, cheaper methods like RT-PCR have more chances of false positives and are not fast enough despite of having high sensitivity. Thus, a CT scan along with the testing can help to overcome the suspected false positive results. Tests based on antibodies on the other hand are super fast, but as antibody generation requires time (minimum 3 days); there are high chances of false negative results which will only create more hindrance during preventing the spread of the disease. Lastly, operating these methods require proper technical skills and training in order to achieve systemic testing; which may not be effective in every region.

\section{NON-SPECIFIC THERAPEUTIC OPTIONS}

Currently, there are no approved vaccines available for use nor is there any specific treatment (151-153). Patients are 
treated symptomatically and observed under intensive care if needed, to provide organ support to severely ill patients $(152,154,155,157)$. It is recommended that patients be provided with supportive care such as hydration, oxygen therapy, pain and bacterial co-infection management etc. $(156,157)$. According to WHO, a vaccine is to emerge in the markets within the next 18 months, given funding and continued public interest in the event the threat diminishes (152). Thus, this necessitates the discovery of new antiviral drug treatments necessary to manage the crisis (152).

\section{Drug Treatment}

IFN a (5 million $U$ bid inh) and lopinavir/ritonavir (400 $\mathrm{mg} / 100 \mathrm{mg}$ bid po) are currently recommended as antiviral therapy by the guidelines (155). Oral oseltamivir has also been implemented in treatment by Chinese hospitals but there is no evidence leading to its effectiveness (158). Favipiravir is yet another broad-spectrum antiviral compound that has been endorsed by Shenzan Health Commission to treat individuals infected with SARS-CoV-2 (159).

The drugs to be explored all come from those used to treat SARS, MERS or any influenza recently encountered (155). In order to carry this out, there are 3 approaches (155). First, to test available broad-spectrum antiviral drugs (that have been previously used to treat other viral infections) via standard assays (160). Second, to screen chemical libraries (of compound or databases) and retrieve knowledge on transcription process in a variety of cell lines (161). Lastly, to redevelop new drugs basing it on the genomic and biophysical virtues of coronavirus. Antiviral drugs follow either one of the following mechanisms of action i.e., viral replication inhibition, ion channel inhibition, serine protease inhibition $(154,162)$ and some of the most promising are listed below:

\section{Remdesivir}

Remdesivir has recently been in news highlights and may be the best potential candidate to be trialed and developed into a future drug (158). The antiviral agent was initially developed to combat Ebola in phase 2 trial and shows broadspectrum antiviral activity $(153,163,164)$. It is not clear how it acts as an adenosine nucleotide analog, however, it is most likely to terminate RNA synthesis leading to mutagenesis (165). It might also compete with RNA dependent RNA polymerase (RdRp) (166). It is said to cause "premature termination by entering the nascent viral RNA (167). As a matter of fact, nucleoside analogs have a number of mechanisms for action which include specific/non-specific chain termination, inhibition of nucleotide biosynthesis and lethal mutagenesis (168). The compound has been effective against viruses related to SARS-CoV-2 and MERS-CoV (169-172). Moreover, in support, another recent study has shown that GS-5734, otherwise known as remdesivir, can work against a wide range of RNA viruses, which include SARS/MERS-CoV, in infected mice and cultured cells as well as non-human primate (NHP) model (167). Another study reported that a patient infected with SARS-CoV-2 had shown positive results upon treatment (52). Two more studies found that the compound could effectively control the infection in vitro $(172,173)$. While a study in 2020 showed that remdesivir received a score of $0.77 \mu \mathrm{M}$ at half proximal concentration against the virus block the infection (172). When used in combination with an inflammatory drug, baricitinib, the efficacy of remdesivir increases (174).
At the moment, remdesivir is undergoing a large number of clinical trials in hospitals but the ultimate competence of the drug is unconfirmed $(153,157,175)$.

\section{Ribavirin}

Ribavirin is a guanosine analog with antiviral activity that is used to treat hepatitis $C$, respiratory syncytial and some haemorrhagic viral fever $(162,176)$. It is commonly used along with interferon a (IFN- $\alpha$ ) (162). In a study that used rhesus macaque model, the antiviral drug favourably treated MERSCoV infection (177). Additionally, this compound targets the RNA dependent RNA polymerase (RdRp) in SARS-CoV-2 as shown in a model that based on sequence analysis, modelling and docking (178). In a study conducted at 2020, ribavirin achieved $109.5 \mu \mathrm{M}$ of half maximal concentration against SARS-CoV-2 which serves to strengthen its potential as an effective drug (178).

\section{Lopinavir and Ritonavir}

Lopinavir, a kind of protease inhibitor used to treat HIV and often used along ritonavir as a booster $(158,162)$. With or without ritonavir, both usages have shown antiviral activity against SARS-CoV-2 in vitro $(176,179)$. Hong Kong scholars found that SARS cases treated with lopinavir/ritonavir and ribavirin had a relatively lower risk of acute respiratory distress syndrome (ARDS) and death, compared to cases treated by ribavirin alone (180). The inhibitor has had success in treating SARS and MERS infections and thus, can potentially fight the SAR-CoV-2 (181). In conjunction with oseltamivir, complete recovery was observed in a patient with SARS-CoV-2 related pneumonia symptoms (182).

Note on Angiotensin-converting Enzyme (ACE) and Angiotensin Receptor Blockers (ARB)

These two drugs are used to treat hypertension by causing an increased expression of ACE2 (153). It is to be noted that, when treated with ACE and ARB, overexpression of ACE2 has been seen in patients with type 1 and type 2 diabetes (35). This is where the SARS-CoV-2 binds in host cells (153). As no strong evidence indicating a higher susceptibility in this group of people has been found, the International Pharmaceutical Federation (FIP) has advised to continue this treatment in patients unless complications arise (153). Theoretically, an ACE2-based peptide, 3CLpro-inhibitor (3CLpro-1) and a vinylsulfone protease inhibitor have been reported to show some antiviral function against SARS-CoV-2 (183).

\section{Chloroquine and Hydroxychloroquine}

Chloroquine and hydroxychloroquine are widely used as an antimalarial and autoimmune disease drug, chloroquine is known for its broad-spectrum antiviral activity (162,184-186). Both chloroquine and hydroxychloroquine are known to be immunomodulatory and suppress the immune system $(187,188)$. Use of chloroquine phosphate has led to some success in treating SAR-CoV-2 associated pneumonia $(156,189)$. Chloroquine works by interference with glycosylation of cellular receptors of the virus itself such as inhibition or alteration during post-translational modifications of proteins synthesized by virus or by increasing endosomal $\mathrm{pH}$ for cell fusion $(186,190)$. One model, physiologically-based pharmacokinetic (PBPK) showed better effectiveness using hydroxychloroquine in SAR-CoV-2 infected Vero cells rather than chloroquine (191). 
In fact, chloroquine has been prescribed for use in the treatment of SAR-CoV-2 related pneumonia $(189,192)$. At half maximal concentration of $1.13 \mu \mathrm{M}$, the drug has blocked viral infection by enhancing the endosomal $\mathrm{pH}$ needed for viral fusion $(172,190)$. However, the optimal dosage still needs to be determined via clinical trials. It is to be noted that the clinical safety and protocols for use for chloroquine (and remdesivir) are yet to be established via phase 3 trials; thus, the pros and cons (toxicity, side-effects or any other complication) must be evaluated carefully before use (153). If these trials are affirmative, both chloroquine and hydroxychloroquine can be applied in prophylaxis and curative treatments in infected patients (193).

\section{Convalescent Plasma Therapy}

As vaccines and drugs are yet to be developed, convalescent plasma therapy could be an effective approach in thwarting the progress of SARS-CoV-2 infection in severe patients (194). A laboratory test succeeded in neutralizing the virus extracted from bronchoalveolar lavage fluid (of a critical case) with sera from a number of patients (40).

Patients who have recovered from SARS-CoV-2 infection produce antibodies against the virus and their serum could be collected and used to prevent reinfection (157). This plasma should be collected within 2 weeks of recovery when the antibody titer is high and can be used to prepare globulin specific to SARS-CoV-2 $(157,176)$. The plasma must be administered within the first week of infection when viremia is very high, in major cases (195). A 2009 prospective cohort study proved that for those infected with $\mathrm{H} 1 \mathrm{~N} 1$ influenza, the relative risk of death was considerably lower in patients treated with convalescent plasma (196). These antibodies restrict viral reproduction during the acute phase of infection and help terminate thriving viruses (197). A retrospective analysis produced that convalescent therapy was more effective in treating severe SARS patients rather than severe doses of hormonal shock in terms of mortality rate and duration of hospital stays (198). The clinical application is hindered by the difficulty posed during obtaining this very plasma (176). Nonetheless, the safety, risks and efficacy associated with these plasma-derivative products need to be assessed further with well-designed clinical trials $(157,176)$.

Given these findings, many drugs have shown satisfactory result in different clinical and laboratory experiments. Although different drugs are in different phases of clinical trials but the differences in drug response from one ethnicity to another is another concern. Variation in different trials with same drug has already been reported but it is expected that a common therapeutic measure will be developed soon.

\section{PROGRESSES IN SARS-COV-2 VACCINE DEVELOPMENT}

At the moment, there is no vaccine for the human coronavirus, SARS-CoV-2 (152,176,194). The surface glycoprotein or spike (S) protein that is involved in cell receptor interaction is being targeted for vaccine development in a majority of trials $(158,199,200)$. There are challenges to be overcome and for an effective vaccine to be readied, quite a time needs to elapse for it to pass regulatory tests that judge its safety (200). Take the case of Ebola pandemic in 2013, when the vaccine Ebola rVSV took 3 years to reach phase I clinical trials in Africa and Europe (201). As per WHO, a suitable vaccine would be available within a time frame of 18 months given there is sufficient funding and public interest even when the threat wanes (202). As of now, 18 biotechnology companies and universities from China are working to bring a vaccine (Table 5). Compared to Ebola, vaccines for SARS-CoV-2 have seen a faster pace due to collaborative efforts by scientists from all over the globe (176).

There is a possibility of re-infection as the humoral immunity weakens over time and the vaccines need to address this issue as well as the problem when the virus becomes endemic and appears recurrently. Individuals over 50 make up most of the severe cases but why this occurs is yet to be cleared; thus, the vaccines should also protect this vulnerable portion of the community (203). However, older individuals generally respond less well to these vaccines because of immune senescence (204).

The first human trial in Europe has begun at Oxford University and plans to study 800 participants half of which will only be injected with the vaccine developed under 3 months. The rest is to be injected with a vaccine that protects against meningitis. The vaccine is said to be very optimistic among the researchers working on it and is based on a weakened version of adenovirus or the common cold virus that affects chimpanzees; this will prevent it from growing in humans. The same team has developed a vaccine against MERS using the same technique and have had promising clinical trials (213). Soon, a larger trial consisting of 5,000 volunteers is to take place and will be specified to no age limit. (214).

Nonetheless, the safety and efficacy of the vaccine are the prime targets set in mind as well as equipment for mass production. Apart from this, the cost of each unit of vaccine must also be considered. The vaccine has to be made available globally and must be affordable by all which is another concern.

\section{SUMMARY}

Coronaviruses have been around for centuries now, within animal and human populations. Although the previously known human coronaviruses until the SARS epidemic did not attract much attention since they were usually not highly pathogenic as compared to SARS-CoV, MERS-CoV and SARSCoV-2, most of them were associated with only mild respiratory conditions.

However, the onset of the SARS and MERS outbreak in the years 2002/2003 and 2012 respectively have exposed the more pathogenic natures of these viruses, resulting in high fatality cases.

The Novel strain of the human Coronavirus named SARSCoV-2 mainly shares the same typical protein and genomic structure as that of all the other coronaviruses however the accessory genes and proteins are known to vary, and also responsible for their dynamic virulence upon mutation (215). Their zoonotic origin and human-human transmission have been confirmed by now. Bats are suspected to be their natural host reservoir due to the high genomic similarities of the SARSCoV-2 with other bat like SARS-CoVs but the intermediate host resulting in the transmission from the animal to human population is still unknown. A statistical report from July 2019 (prior to the COVID-19 outbreak) to determine the serological 
Table 5. Various undergoing SARS-CoV-2 vaccine development projects in 2020

\begin{tabular}{|c|c|}
\hline Type of vaccine & Companies working \\
\hline $\begin{array}{l}\text { 1. Live-attenuated } \\
\text { vaccine }\end{array}$ & $\begin{array}{l}\text { Codagenix, Inc. in collaboration with Serum Institute } \\
\text { of India, Ltd. are working to develop a live-attenuatec } \\
\text { vaccine }(200)\end{array}$ \\
\hline $\begin{array}{l}\text { 2. } \mathrm{mRNA} \\
\text { vaccine }\end{array}$ & $\begin{array}{l}\text { A vaccine, mRNA-1273 by Moderna is to go on trials by } \\
\text { the end of April, } 2020 \text { (200). More companies include } \\
\text { Baylor College of Medicine, BDGENE, CanSino } \\
\text { Biologics Inc., CureVac AG, Guanhao Biotech, ZY } \\
\text { Therapeutics Inc., Stermirna Therapeutics, University } \\
\text { of Texas and Tongji University are working each on } \\
\text { their versions. (200). Fudan University with Shanghai } \\
\text { Jiaotong University and Bluebird Pharmaceutical } \\
\text { Company have } 2 \text { strategies planned to produce an } \\
\text { mRNA vaccine (200). }\end{array}$ \\
\hline
\end{tabular}

Other details

This type of vaccine presents multiple antigens in the host to

induce a range of immunogenic effectors against the pathogen (205).

The project by Fudan University aims to use mRNA that would express the $\mathrm{S}$ protein and RBD domain and is being tested on mice (200). The other is based on mRNA producing virus-like particles in vivo. Moderna plans to express $S$ proteins as well and will test it on 20-25 healthy volunteers soon (200). It is known to possess LNPencapsulated mRNA vaccine encoding $\mathrm{S}$ protein and is currently at phase I (206)

Ad5-nCoV by CanSino Biologics Inc. uses type 5 adenovirus vector to express $S$ protein and is also at phase 1 (206).

mRNA vaccines are opted by so many companies owing to lowcost, safe administration, high potency and quick production cycles compare to traditional vaccines (207). However, so far there has been no mRNA vaccine in the market thus, it is likely to take more time to pass safety evaluation and other quality standard testing (200).

3. Live vector Johnson \& Johnson has validated an adenoviral vaccine $\quad$ vector, $\operatorname{AdVac}^{\circledast}$ (208), Tonix Pharmaceuticals is Live vector vaccines are said to me made of live viruses that express heterologous antigens (200). Such vaccines are said to researching on horsepox virus (TNX-1800) and Greffex have the strong immunogenicity of live-attenuated vaccines and Inc. has announced to have completed an adenovirus the safety of subunit vaccines (200). vaccine in association with Greffex Vector Platform (200).

4. DNA vaccine Two DNA vaccines are under development. One of them being INO-4800 by Inovio Pharmaceuticals. LineaRx, Applied DNA Sciences Subsidiary and Takis Biotech are working on a linear DNA vaccine candidate (200).

5. Epitope vaccine Generex Biotechnology is working together with third- This type of vaccines is easy to produce and ass the quality control party groups to create a vaccine that uses synthetic peptide to copy key viral regions that is linked to an amino acid residue (200)

A team from Hong Kong University of Science and Technology found epitopes highly conserved in SARSCoV-2 which has the potential to contribute to a vaccine (210).

6. Subunit vaccine Chongqing Zhifei

Biological Products Co., Ltd, Johnson \& Johnson and Pasteur Institute are all working on their own subunit types (200).

Clover Biopharmaceuticals Inc. has made it public that they are currently working on a vaccine that would use "trimer-tag" technology (211) whereas University of Queensland is progressing via "molecular clamp technology" (212).

Lastly, Novavax Inc. has a one of a kind candidates in line, nanoparticle vaccines based on the $S$ protein (200).

evidence of the spillover of viruses from bats to humans in more rural settings Southern China did not show any direct relationship between bat contact and the infections of coronavirus within the sample population however most infections seemed to have a correlation with domestic animal exposure thus indicating the presence of an intermediate host (216). With different mode of transmission and host being reported, ranges about it is yet to be unveiled.

There is no approved specific drug available to cure COVID19 and so preventive measures are now the general solutions. Chloroquine and hydroxychloroquine have shown inhibition of virus in vitro although the dose required for humans is estimated to be high to cause severe toxicity. Both of the compounds have been issued by the FDA as an emergency despite no conclusive evidence of their efficacy.
Inovio intends to deliver a plasmid coding for $\mathrm{S}$ protein by electroporation and has entered its phase 1 trials (206).

(200). But cons include, low immunogenicity due to low molecular weight and complex structure and call for the need to change in formulation by introducing structural changes, adjuvants and such (209).

Generex is working on a patented technology called the NuGenerex Immuno-Oncology li-Key technology (200).

There are 15 candidates to this type (206). Most of these are using S proteins as antigens (200).

These vaccines are much safer and easier to produce with the added benefit of efficient stimulation of host immune system (200). Very often, they require adjuvants for a strong response (200).
Hydroxychloroquine can cause several side-effects like, cardiomyopathy, however rarely, and this can only be treated by immediate discontinuation in some cases $(217,218)$.

Tocilizumab is a humanized monoclonal antibody of IgG1 sub-class known to inhibit cytokine, interleukine-6 (IL-6) receptor bringing about immunosuppression. Recent findings from China has suggested that the mortality may be a cause of viral hyperinflammation. This drug is also being tested in patients especially vulnerable to cytokine release syndrome that is triggered by the infection (220). We know that immunosuppression is not advised to treat viral infections and may intensify the symptoms of COVID-19, however, this may prove to be beneficial in case of cytokine storm. In China, its use has been approved for patients suffering from pneumonia and elevated levels of IL-6. Hence, it is recommended that the 
severe cases of hyperinflammation be highlighted and treated using this approach to see if it works $(217,219-222)$. With different antiviral and other drugs being under clinical trial, an efficient therapeutic option is expected to be discovered soon.

While many vaccine projects are currently being worked at, one concern is the potential of the already approved BCG vaccine. Modeling this vaccine to combat COVID-19 means that the efficacy needs to be determined via phase 3 trials only saving at least a year of time. Abundance Foundation is one such example being funded for trials.

Zinc sulfate has been used successfully to treat a number of medical problems such as, herpes simplex infection, viral warts, acute cutaneous leishmaniasis and in therapy of autoimmune diseases like, Behcet's disease, alopecia areata. Hence, it is suggested that the use of oral zinc in BCG vaccines could prove positively against COVID-19 (223-229).

\section{CONCLUDING REMARKS}

As an emerging virus, most about SARS-CoV-2 is still to be unveiled and again the contagious nature of the virus makes it impervious to fight against the pandemic. Appropriate preventive measures, early diagnosis and non-specific treatments in critical cases are the general options today to combat the outbreak. Better understanding of the virus structure, genetics and the concurrent scientific effort to develop counter measure against the virus are the present global needs. All in all, the prime concern worldwide is to develop an effective vaccination and responsive drugs before it is too late. Normalcy as we know it cannot return until there is a safe vaccine ready. So far, the structure for SAR-CoV-2 has been revealed. The underlying problem is progress of trials of prospective anti-viral drugs. While hundreds of projects are ongoing, scientists all over the globe need to collaborate their findings to bring out a formula that would sell without profits. Having said that, a test kit that would detect the virus within minutes whilst being affordable is also a genuine concern. Current methods take too long and have trouble with accuracy given the huge load of samples that demand to be processed every day. However, more effective and sensitive diagnosis methods might be in the development.

\section{ACKNOWLEDGEMENT}

Authors acknowledge the members of Swift Integrity Computational Lab, Dhaka, Bangladesh, a virtual platform of young researchers for their support during the preparation of the manuscript.

\section{REFERENCES}

1. Zhu N, Zhang D, Wang W, Li X, Yang B, Song J, et al. A novel coronavirus from patients with pneumonia in China, 2019. New England Journal of Medicine. 2020 Jan 24. https://doi.org/10.1056/NEJMoa2001017 PMid:31978945 PMCid:PMC7092803

2. Cui J, Li F, Shi ZL. Origin and evolution of pathogenic coronaviruses. Nature reviews Microbiology. 2019 Mar;17(3):181-92. https://doi.org/10.1038/s41579-0180118-9 PMid:30531947 PMCid:PMC7097006
3. Woo PC, Lau SK, Lam CS, Lau CC, Tsang AK, Lau JH, et al. Discovery of seven novel Mammalian and avian coronaviruses in the genus deltacoronavirus supports bat coronaviruses as the gene source of alphacoronavirus and betacoronavirus and avian coronaviruses as the gene source of gammacoronavirus and deltacoronavirus. Journal of virology. 2012 Apr 1;86(7):3995-4008. https://doi.org/10.1128/JVI.06540-11 PMid:22278237 PMCid:PMC3302495

4. Wang LF, Shi Z, Zhang S, Field H, Daszak P, Eaton BT. Review of bats and SARS. Emerging infectious diseases. 2006 Dec;12(12):1834. https://doi.org/10.3201/eid1212. 060401 PMid:17326933 PMCid:PMC3291347

5. Chen Y, Guo D. Molecular mechanisms of coronavirus RNA capping and methylation. VirologicaSinica. 2016 Feb 1;31(1):3-11. https://doi.org/10.1007/s12250-016-3726-4 PMid:26847650 PMCid:PMC7091378

6. Snijder EJ, Van Der Meer Y, Zevenhoven-Dobbe J, Onderwater JJ, van der Meulen J, Koerten HK, Mommaas AM. Ultrastructure and origin of membrane vesicles associated with the severe acute respiratory syndrome coronavirus replication complex. Journal of virology. 2006 Jun 15;80(12):5927-40. https://doi.org/10.1128/JVI.0250105 PMid:16731931 PMCid:PMC1472606

7. Chen Y, Liu Q, Guo D. Emerging coronaviruses: genome structure, replication, and pathogenesis. Journal of medical virology. 2020 Apr;92(4):418-23. https://doi.org/ 10.1002/jmv.25681 PMid:31967327 PMCid:PMC7167049

8. Tyrrell DA, Bynoe ML. Cultivation of a novel type of common-cold virus in organ cultures. British medical journal. 1965 Jun 5;1(5448):1467. https://doi.org/10.1136/ bmj.1.5448.1467 PMid:14288084 PMCid:PMC2166670

9. Perlman P. Fields Virology. 2nd ed. 2013:825-58.

10. Su S, Wong G, Shi W, Liu J, Lai AC, Zhou J, et al. Epidemiology, genetic recombination, and pathogenesis of coronaviruses. Trends in microbiology. 2016 Jun 1;24(6):490-502. https://doi.org/10.1016/j.tim.2016.03.003 PMid:27012512 PMCid:PMC7125511

11. Forni D, Cagliani R, Clerici M, Sironi M. Molecular evolution of human coronavirus genomes. Trends in microbiology. 2017 Jan 1;25(1):35-48. https://doi.org/10.1016/j.tim. 2016.09.001 PMid:27743750 PMCid:PMC7111218

12. Fehr AR, Perlman S. Coronaviruses: an overview of their replication and pathogenesis. In Coronaviruses 2015 (pp. 123). Humana Press, New York, NY. https://doi.org/10.1007/ 978-1-4939-2438-7_1 PMid:25720466 PMCid:PMC4369385

13. World Health Organization. Severe Acute Respiratory Syndrome (SARS)-multi-country outbreak-update 36 . Outbreak reported March. 2003 Apr 8;19.

14. Parry J. WHO investigates China's fall in SARS cases. BMJ: British Medical Journal. 2003 Jun 14;326(7402):1285. https://doi.org/10.1136/bmj.326.7402.1285-c PMid:12805143 PMCid:PMC1126174

15. Guan Y, Zheng BJ, He YQ, Liu XL, Zhuang ZX, Cheung CL, et al. Isolation and characterization of viruses related to the SARS coronavirus from animals in southern China. Science. 2003 Oct 10;302(5643):276-8. https://doi.org/10.1126/ science.1087139 PMid:12958366

16. Perlman S, Netland J. Coronaviruses post-SARS: update on replication and pathogenesis. Nature reviews microbiology. 2009 Jun;7(6):439-50. https://doi.org/ 10.1038/nrmicro2147 PMid:19430490 PMCid:PMC2830095 
17. Lau SK, Li KS, Huang Y, Shek CT, Tse H, Wang M, et al. Ecoepidemiology and complete genome comparison of different strains of severe acute respiratory syndromerelated Rhinolophus bat coronavirus in China reveal bats as a reservoir for acute, self-limiting infection that allows recombination events. Journal of virology. $2010 \mathrm{Mar}$ 15;84(6):2808-19. https://doi.org/10.1128/JVI.02219-09 PMid:20071579 PMCid:PMC2826035

18. Chan-Yeung M, Xu RH. SARS: Epidemiology. Respirology 8: S9-S14. https://doi.org/10.1046/j.1440-1843.2003.00518.x PMid:15018127 PMCid:PMC7169193

19. Zaki AM, Van Boheemen S, Bestebroer TM, Osterhaus AD, Fouchier RA. Isolation of a novel coronavirus from a man with pneumonia in Saudi Arabia. New England Journal of Medicine. 2012 Nov 8;367(19):1814-20. https://doi.org/ 10.1056/NEJMoa1211721 PMid:23075143

20. Lee J, Chowell G, Jung E. A dynamic compartmental model for the Middle East respiratory syndrome outbreak in the Republic of Korea: a retrospective analysis on control interventions and superspreading events. Journal of theoretical biology. 2016 Nov 7;408:118-26. https://doi.org/10.1016/j.jtbi.2016.08.009 PMid:27521523 PMCid:PMC7094115

21. Lee JY, Kim YJ, Chung EH, Kim DW, Jeong I, Kim Y, et al. The clinical and virological features of the first imported case causing MERS-CoV outbreak in South Korea, 2015. BMC infectious diseases. 2017 Dec 1;17(1):498. https://doi.org/10.1186/s12879-017-2576-5 PMid:28709419 PMCid:PMC5512736

22. Huang C, Wang Y, Li X, Ren L, Zhao J, Hu Y, et al. Clinical features of patients infected with 2019 novel coronavirus in Wuhan, China. The Lancet. 2020 Feb 15;395(10223):497506. https://doi.org/10.1016/S0140-6736(20)30183-5

23. Chan JF, Yuan S, Kok KH, To KK, Chu H, Yang J, et al. A familial cluster of pneumonia associated with the 2019 novel coronavirus indicating person-to-person transmission: a study of a family cluster. The Lancet. 2020 Feb 15;395(10223):514-23. https://doi.org/10.1016/S01406736(20)30154-9

24. Yoo JH. The fight against the 2019-nCoV outbreak: an arduous march has just begun. Journal of Korean Medical Science. 2019 Dec 24;35(4). https://doi.org/10.3346/ jkms.2020.35.e56 PMid:31997618 PMCid:PMC6995816

25. Beniac DR, Andonov A, Grudeski E, Booth TF. Architecture of the SARS coronavirus prefusion spike. Nature structural \& molecular biology. 2006 Aug;13(8):751-2. https://doi.org/10.1038/nsmb1123 PMid:16845391 PMCid:PMC7097490

26. Delmas BE, Laude HU. Assembly of coronavirus spike protein into trimers and its role in epitope expression. Journal of Virology. 1990 Nov 1;64(11):5367-75. https://doi.org/10.1128/JVI.64.11.5367-5375.1990 PMid:2170676 PMCid:PMC248586

27. Nal B, Chan C, Kien F, Siu L, Tse J, Chu K, et al. Differential maturation and subcellular localization of severe acute respiratory syndrome coronavirus surface proteins $S, M$ and E. Journal of general virology. 2005 May 1;86(5):142334. https://doi.org/10.1099/vir.0.80671-0 PMid:15831954

28. Neuman BW, Kiss G, Kunding AH, Bhella D, Baksh MF, Connelly $\mathrm{S}$, et al. A structural analysis of $\mathrm{M}$ protein in coronavirus assembly and morphology. Journal of structural biology. 2011 Apr 1;174(1):11-22. https://doi.org/10.1016/j.jsb.2010.11.021 PMid:21130884 PMCid:PMC4486061
29. DeDiego ML, Álvarez E, Almazán F, Rejas MT, Lamirande E, Roberts $A$, et al. A severe acute respiratory syndrome coronavirus that lacks the $E$ gene is attenuated in vitro and in vivo. Journal of virology. 2007 Feb 15;81(4):1701-13. https://doi.org/10.1128/JVI.01467-06 PMid:17108030 PMCid:PMC1797558

30. Nieto-Torres JL, DeDiego ML, Verdia-Baguena C, JimenezGuardeno JM, Regla-Nava JA, Fernandez-Delgado R, et al. Severe acute respiratory syndrome coronavirus envelope protein ion channel activity promotes virus fitness and pathogenesis. PLoS pathogens. 2014 May;10(5). https://doi.org/10.1371/journal.ppat.1004077 PMid:24788150 PMCid:PMC4006877

31. Bogoch II, Watts A, Thomas-Bachli A, Huber C, Kraemer MU, Khan K. Pneumonia of Unknown Etiology in Wuhan, China: Potential for International Spread Via Commercial Air Travel. Journal of Travel Medicine. 2020 Jan 14. https://doi.org/10.1093/jtm/taaa008 PMid:31943059 PMCid:PMC7107534

32. Lu R, Zhao X, Li J, Niu P, Yang B, Wu H, et al. Genomic characterisation and epidemiology of 2019 novel coronavirus: implications for virus origins and receptor binding. The Lancet. 2020 Feb 22;395(10224):565-74. https://doi.org/10.1016/S0140-6736(20)30251-8

33. Wu Y, Ho W, Huang Y, Jin DY, Li S, Liu SL, et al. SARS-CoV-2 is an appropriate name for the new coronavirus. The Lancet. $2020 \quad$ Mar 21;395(10228):949-50. https://doi.org/10.1016/S0140-6736(20)30557-2

34. Zhang YZ, Holmes EC. A genomic perspective on the origin and emergence of sars-cov-2. Cell. 2020 Mar 26. https://doi.org/10.1016/j.cell.2020.03.035 PMid:32220310 PMCid:PMC7194821

35. Wan Y, Shang J, Graham R, Baric RS, Li F. Receptor recognition by the novel coronavirus from Wuhan: an analysis based on decade-long structural studies of SARS coronavirus. Journal of virology. 2020 Mar 17;94(7). https://doi.org/10.1128/JVI.00127-20

36. Zhang Z, Wu Q, Zhang T. Pangolin homology associated with 2019-nCoV. bioRxiv. 2020 Jan 1. https://doi.org/10.1101/2020.02.19.950253

37. Coronavirus [Internet]. Who.int. 2020 [cited 17 April 2020]. Available at: https://www.who.int/emergencies/diseases/ novel-coronavirus-2019

38. Shereen M, Khan S, Kazmi A, Bashir N, Siddique R. COVID19 infection: Origin, transmission, and characteristics of human coronaviruses. Journal of Advanced Research. 2020;24:92. https://doi.org/10.1016/j.jare.2020.03.005 PMid:32257431 PMCid:PMC7113610

39. Wang C, Horby P, Hayden F, Gao G. A novel coronavirus outbreak of global health concern. The Lancet. 2020;395(10223):470, 471. https://doi.org/10.1016/S01406736(20)30185-9

40. Zhou P, Yang X, Wang X, Hu B, Zhang L, Zhang W, et al. A pneumonia outbreak associated with a new coronavirus of probable bat origin. Nature. 2020;579(7798):270. https://doi.org/10.1038/s41586-020-2012-7 PMid:32015507 PMCid:PMC7095418

41. Wu F, Zhao S, Yu B, Chen Y, Wang W, Song Z, et al. A new coronavirus associated with human respiratory disease in China. Nature. 2020;579(7798):265. https://doi.org/10.1038 /s41586-020-2008-3 PMid:32015508 PMCid:PMC7094943 
42. Kutter J, Spronken M, Fraaij P, Fouchier R, Herfst S. Transmission routes of respiratory viruses among humans. Current Opinion in Virology. 2018;28:142. https://doi.org/10.1016/j.coviro.2018.01.001 PMid:29452994 PMCid:PMC7102683

43. Little L. Coronavirus symptoms day-by-day - when to expect signs of killer bug to strike [Internet]. The US Sun. 2020 [cited 12 April 2020]. Available at: https://www.thesun.com/news/554654/coronavirus-symptoms-day-byday-when-to-expect-signs-of-killer-bug-to-strike/

44. [Internet]. Cdc.gov. 2020 [cited 12 April 2020]. Available at: https://www.cdc.gov/coronavirus/2019-ncov/downloads/ 2019-ncov-factsheet.pdf

45. Pregnant women with coronavirus infection can pass it to their babies, study finds [Internet]. Los Angeles Times. 2020 [cited 18 April 2020]. Available at: https://www.latimes. com/science/story/2020-03-26/coronavirus-pregnantwomen-with-covid-19-babies

46. Karimi-Zarchi M, Neamatzadeh $H$, Dastgheib S, Abbasi $H$, Mirjalili S, Behforouz A, et al. Vertical Transmission of Coronavirus Disease 19 (COVID-19) from Infected Pregnant Mothers to Neonates: A Review. Fetal and Pediatric Pathology. 2020:1. https://doi.org/10.1080/15513815.2020. 1747120 PMCid:PMC7157948

47. How a Bronx Zoo tiger was tested for coronavirus [Internet]. New York Post. 2020 [cited 18 April 2020]. Available at: https://nypost.com/2020/04/12/how-a-bronxzoo-tiger-was-tested-for-coronavirus/

48. The Real Reason Veterinarians Gave a Tiger a Covid-19 Test ... [Internet]. [cited 2020Apr27]. Available at: https://www. wired.com/story/tiger-coronavirus-bronx-zoo/

49. Coronavirus Update (Live): $1,830,982$ Cases and 113,008 Deaths from COVID-19 Virus Pandemic - Worldometer [Internet]. Worldometers.info. 2020 [cited 12 April 2020]. Available at: https://www.worldometers.info/coronavirus/

50. Peiris JS, Yuen KY, Osterhaus AD, Stöhr K. The severe acute respiratory syndrome. New England Journal of Medicine. 2003 Dec 18;349(25):2431-41. https://doi.org/10.1056/ NEJMra032498 PMid:14681510

51. Tai W, He L, Zhang X, Pu J, Voronin D, Jiang S, et al. Characterization of the receptor-binding domain (RBD) of 2019 novel coronavirus: implication for development of RBD protein as a viral attachment inhibitor and vaccine. Cellular \& Molecular Immunology. 2020. https://doi.org/ 10.1038/s41423-020-0400-4 PMCid:PMC7091888

52. Holshue M, DeBolt C, Lindquist S, Lofy K, Wiesman J, Bruce $\mathrm{H}$, et al. First Case of 2019 Novel Coronavirus in the United States. New England Journal of Medicine. 2020;382(10). https://doi.org/10.1056/NEJMoa2001191 PMid:32004427 PMCid:PMC7092802

53. With Europe's first confirmed coronavirus cases, how is France dealing with the disease? [Internet]. France 24. 2020 [cited 12 April 2020]. Available at: https://www.france24. com/en/20200126-france-china-coronavirus-china-wuhan -disease-epidemic-buzyn-who-paris-hidalgo-lunar-newyear-bordeaux

54. First confirmed case of novel coronavirus in Australia [Internet]. Australian Government Department of Health. 2020 [cited 12 April 2020]. Available at: https://www. health. gov.au/ministers/the-hon-greg-hunt-mp/media/firstconfirmed-case-of-novel-coronavirus-in-australia
55. Contributor S. Scientists figure out how new coronavirus breaks into human cells [Internet]. livescience.com. 2020 [cited 13 April 2020]. Available at: https://www.livescience. com/how-coronavirus-infects-cells.html

56. Wrapp D, Wang N, Corbett K, Goldsmith J, Hsieh C, Abiona O, et al. Cryo-EM structure of the 2019-nCoV spike in the prefusion conformation. Science. 2020;367(6483):1260. https://doi.org/10.1126/science.abb2507 PMid:32075877 PMCid:PMC7164637

57. Yan R, Zhang Y, Li Y, Xia L, Guo Y, Zhou Q. Structural basis for the recognition of SARS-CoV-2 by full-length human ACE2. Science. 2020;367(6485):1444. https://doi.org/10. 1126/science.abb2762 PMid:32132184 PMCid:PMC7164635

58. Why does the coronavirus spread so easily between people? [Internet]. Nature.com. 2020 [cited 13 April 2020]. Available at: https://www.nature.com/articles/d41586020-00660-x

59. Coutard B, Valle C, de Lamballerie X, Canard B, Seidah N, Decroly $E$. The spike glycoprotein of the new coronavirus 2019-nCoV contains a furin-like cleavage site absent in CoV of the same clade. Antiviral Research. 2020;176:104742. https://doi.org/10.1016/j.antiviral.2020.104742 PMid:32057769 PMCid:PMC7114094

60. Belouzard S, Millet J, Licitra B, Whittaker G. Mechanisms of Coronavirus Cell Entry Mediated by the Viral Spike Protein. Viruses. 2012;4(6):1014. https://doi.org/10.3390/v4061011 PMid:22816037 PMCid:PMC3397359

61. (COVID-19) C, Health E, Disease H, Disease L, Management $\mathrm{P}$, Conditions $\mathrm{S}$ et al. What Does Coronavirus Do to Your Body? [Internet]. WebMD. 2020 [cited 13 April 2020]. Available at: https://www.webmd.com/lung/coronaviruscovid-19-affects-body\#1

62. M.N. Iqbal H, Romero-Castillo K, Bilal M, Parra-Saldivar R. The Emergence of Novel-Coronavirus and its Replication Cycle - An Overview. Journal of Pure and Applied Microbiology. 2020;14(1):16. https://doi.org/10.22207/ JPAM.14.1.03

63. Zhou F, Yu T, Du R, Fan G, Liu Y, Liu Z, et al. Clinical course and risk factors for mortality of adult inpatients with COVID-19 in Wuhan, China: a retrospective cohort study. The Lancet. 2020;395(10229):1054-62. https://doi.org/ 10.1016/S0140-6736(20)30566-3

64. Coronavirus Incubation Period (COVID-19) - Worldometer [Internet]. Worldometers.info. 2020 [cited 18 April 2020]. Available at: https://www.worldometers.info/coronavirus/ coronavirus-incubation-period/

65. Coronavirus Disease 2019 (COVID-19) [Internet]. Centers for Disease Control and Prevention. 2020 [cited 18 April 2020]. Available at: https://www.cdc.gov/coronavirus/2019-ncov/ hcp/clinical-guidance-management-patients.html

66. Guan W, Ni Z, Hu Y, Liang W, Ou C, et al. Clinical Characteristics of Coronavirus Disease 2019 in China. New England Journal of Medicine. 2020. Available at: https://www.nejm.org/doi/full/10.1056/NEJMoa2002032

67. Chen N, Zhou M, Dong X, Qu J, Gong F, et al. Epidemiological and clinical characteristics of 99 cases of 2019 novel coronavirus pneumonia in Wuhan, China: a descriptive study. The Lancet, 2020;395(10223):507. https://doi.org/10.1016/S0140-6736(20)30211-7

68. Wang D, Hu B, Hu C, Zhu F, Liu X, et al. Clinical Characteristics of 138 Hospitalized Patients With 2019 Novel Coronavirus-Infected Pneumonia in Wuhan, China. JAMA, 2020;323(11):1061. https://doi.org/10.1001/ jama.2020.1585 PMid:32031570 PMCid:PMC7042881 
69. Xu X, Wu X, Jiang X, Xu K, Ying L, et al. Clinical findings in a group of patients infected with the 2019 novel coronavirus (SARS-Cov-2) outside of Wuhan, China: retrospective case series. BMJ, 2020;p.m606. https://doi.org/10.1136/ bmj.m606 PMid:32075786

70. Wu C, Chen X, Cai Y, Xia J, Zhou X, et al. Risk Factors Associated With Acute Respiratory Distress Syndrome and Death in Patients With Coronavirus Disease 2019 Pneumonia in Wuhan, China. JAMA Internal Medicine. 2020. https://doi.org/10.1001/jamainternmed.2020.0994 PMCid:PMC7070509

71. Pan L, Mu M, Yang $P$, Sun $Y$, Wang $R$, et al. Clinical Characteristics of COVID-19 Patients With Digestive Symptoms in Hubei, China. The American Journal of Gastroenterology, 2020:1. https://doi.org/10.14309/ ajg.0000000000000620 PMid:32287140 PMCid:PMC7172492

72. [Internet]. Who.int. 2020 [cited 13 April 2020]. Available at: https://www.who.int/docs/default-source/searo/timorleste/11-02-2020-tls-sitrep-7-ncov-final.pdf?sfvrsn=72720e 51_2

73. China's National Health Commission news conference on coronavirus [Internet]. Aljazeera.com. 2020 [cited 13 April 2020]. Available at: https://www.aljazeera.com/news/2020 /01/chinas-national-health-commission-news-conferencecoronavirus-200126105935024.html

74. How Coronavirus Symptoms Start, And What You Can Expect Each Day [Internet]. IFLScience. 2020 [cited 13 April 2020]. Available at: https://www.iflscience.com/healthand-medicine/a-daybyday-breakdown-of-coronavirussymptoms-shows-how-the-disease-covid19-goes-frombad-to-worse/

75. A day-by-day breakdown of coronavirus symptoms shows how the disease COVID-19 goes from bad to worse [Internet]. Business Insider. 2020 [cited 13 April 2020]. Available at: https://www.businessinsider.com/corona virus-covid19-day-by-day-symptoms-patients-2020-2

76. What to do if you are sick with 2019 Novel Coronavirus. Available at: https://www.cdc.gov/coronavirus/2019-ncov/ prevent-getting-sick/prevention.html

77. World Health Organization, Novel Coronavirus (2019-nCoV) Advice for the Public, (2020). Available at: https://www. who.int/emergencies/diseases/novel-coronavirus-2019/ advice-for-public

78. Infection prevention and control during health care when COVID-19 is suspected. Available at: https://www.who.int/ publications-detail/infection-prevention-and-control-duri ng-health-care-when-novel-coronavirus-(ncov)-infectionis-suspected-20200125

79. Chen X, Shang Y, Yao S, Liu R, Liu H. Perioperative care provider's considerations in managing patients with the COVID-19 infections. Transl Perioper Pain Med. 2020;7:216 23. https://doi.org/10.31480/2330-4871/116

80. Infection Prevention and Control for the safe management of a dead body in the context of COVID-19. Available at: https://apps.who.int/iris/bitstream/handle/10665/331538/ WHO-COVID-19-IPC_DBMgmt-2020.1-eng.pdf?fbclid=IwAR 1h_FQalFcghLAGfFdWoCogtNzVcDUGtFLcfTjLqUUZ4IsYiiR E8k-140A

81. Characteristics of Infectious Disease | Microbiology. Available at: https://courses.lumenlearning.com/micro biology/chapter/characteristics-of-infectious-disease/
82. Backer JA, Klinkenberg D, Wallinga J. Incubation period of 2019 novel coronavirus (2019-nCoV) infections among travellers from Wuhan, China, 20-28 January 2020. Eurosurveillance. $\quad 2020 \quad$ Feb 6;25(5):2000062. https://doi.org/10.2807/1560-7917.ES.2020.25.5.2000062 PMid:32046819 PMCid:PMC7014672

83. Linton NM, Kobayashi T, Yang Y, Hayashi K, Akhmetzhanov $A R$, Jung SM, et al. Incubation period and other epidemiological characteristics of 2019 novel coronavirus infections with right truncation: a statistical analysis of publicly available case data. Journal of clinical medicine. 2020 Feb;9(2):538. https://doi.org/10.3390/jcm9020538 PMid:32079150 PMCid:PMC7074197

84. Lauer SA, Grantz KH, Bi Q, Jones FK, Zheng Q, Meredith HR, et al. The incubation period of coronavirus disease 2019 (COVID-19) from publicly reported confirmed cases: estimation and application. Annals of internal medicine. 2020 Mar 10. https://doi.org/10.7326/M20-0504 PMid:32150748 PMCid:PMC7081172

85. Q\&A on coronaviruses (COVID-19) [Internet]. Who.int. 2020 [cited 14 April 2020]. Available at: https://www.who.int/ news-room/q-a-detail/q-a-coronaviruses

86. Coronavirus Disease 2019 (COVID-19) [Internet]. Centers for Disease Control and Prevention. 2020 [cited 14 April 2020]. Available at: https://www.cdc.gov/coronavirus/2019ncov/faq.html

87. Department of Health | 2.2 The reproduction number [Internet]. www1.health.gov.au. 2020 [cited 14 April 2020]. Available at: https://www1.health.gov.au/internet/publica tions/publishing.nsf/Content/mathematical-models mathematical-models-models.htm mathematicalmodels-2.2.htm

88. Epidemic theory (effective \& basic reproduction numbers, epidemic thresholds) \& techniques for analysis of infectious disease data (construction \& use of epidemic curves, generation numbers, exceptional reporting \& identification of significant clusters) [Internet]. Health Knowledge. 2020 [cited 14 April 2020]. Available at: https:// www.healthknowledge.org.uk/public-health-textbook/ research-methods/1a-epidemiology/epidemic-theory

89. Rothman KJ, Lash T, Greenland S. Modern Epidemiology (3rd ed.), Lippincott Williams \& Wilkins, 2013.

90. Dietz K. The estimation of the basic reproduction number for infectious diseases. Statistical methods in medical research. 1993 Mar;2(1):23-41. https://doi.org/10.1177/ 096228029300200103 PMid:8261248

91. Guerra FM, Bolotin S, Lim G, Heffernan J, Deeks SL, Li Y, Crowcroft NS. The basic reproduction number (R0) of measles: a systematic review. The Lancet Infectious Diseases. 2017 Dec 1;17(12):e420-8. https://doi.org/ 10.1016/S1473-3099(17)30307-9

92. Zhao S, Lin Q, Ran J, Musa S, Yang G, Wang W, et al. Preliminary estimation of the basic reproduction number of novel coronavirus (2019-nCoV) in China, from 2019 to 2020: A data-driven analysis in the early phase of the outbreak. International Journal of Infectious Diseases. 2020;92:214-7. https://doi.org/10.1016/j.ijid.2020.01.050 PMid:32007643 PMCid:PMC7110798

93. Cowling B, Fang V, Riley S, Malik Peiris J, Leung G. Estimation of the Serial Interval of Influenza. Epidemiology. 2009;20(3):344-7. https://doi.org/10.1097/EDE.0b013e3181 9d1092 PMid:19279492 PMCid:PMC3057478 
94. Wu JT, Leung K, Leung GM. Nowcasting and forecasting the potential domestic and international spread of the 2019-nCoV outbreak originating in Wuhan, China: a modelling study. The Lancet. 2020 Feb 29;395(10225):68997. https://doi.org/10.1016/S0140-6736(20)30260-9

95. Li Q, Guan X, Wu P, Wang X, Zhou L, Tong Y, et al. Early transmission dynamics in Wuhan, China, of novel coronavirus-infected pneumonia. New England Journal of Medicine. 2020 Jan 29. Available at: https://www.nejm.org/doi/full/10.1056/NEJMoa2001316

96. Perlman S. Another Decade, Another Coronavirus. New England Journal of Medicine. 2020;382(8):760-2. https://doi.org/10.1056/NEJMe2001126 PMid:31978944 PMCid:PMC7121143

97. Sanche S, Lin Y, Xu C, Romero-Severson E, Hengartner N, Ke R. High Contagiousness and Rapid Spread of Severe Acute Respiratory Syndrome Coronavirus 2. Emerging Infectious Diseases. 2020;26(7). https://doi.org/10.3201/ eid2607.200282 PMid:32255761

98. Bi Q, Wu Y, Mei S, Ye C, Zou X, Zhang Z, et al. Epidemiology and Transmission of COVID-19 in Shenzhen China: Analysis of 391 cases and 1,286 of their close contacts. 2020. https://doi.org/10.1101/2020.03.03.20028423

99. Liu Y, Gayle A, Wilder-Smith A, Rocklöv J. The reproductive number of COVID-19 is higher compared to SARS coronavirus. Journal of Travel Medicine. 2020;27(2). https://doi.org/10.1093/jtm/taaa021 PMid:32052846 PMCid:PMC7074654

100. World Health Organization. Report of the WHO-China joint mission on coronavirus disease 2019 (covid-19). Available at: https://www.who.int/publications-detail/report-ofthe-who-china-joint-mission-on-coronavirus-disease2019-(covid-19)

101. Peeri N, Shrestha N, Rahman M, Zaki R, Tan Z, Bibi S, et al. The SARS, MERS and novel coronavirus (COVID-19) epidemics, the newest and biggest global health threats: what lessons have we learned?. International Journal of Epidemiology. 2020. https://doi.org/10.1093/ije/dyaa033 PMid:32086938 PMCid:PMC7197734

102. Virlogeux V, Fang VJ, Park M, Wu JT, Cowling BJ. Comparison of incubation period distribution of human infections with MERS-CoV in South Korea and Saudi Arabia. Scientific reports. 2016 Oct 24;6:35839. https://doi.org/10.1038/srep35839 PMid:27775012 PMCid:PMC5075793

103. Frequently asked questions on Middle East respiratory syndrome coronavirus. Available at: https://www.who.int/ csr/disease/coronavirus_infections/faq/en/

104. Chowell G, Blumberg S, Simonsen L, Miller MA, Viboud C. Synthesizing data and models for the spread of MERS-CoV, 2013: key role of index cases and hospital transmission. Epidemics. 2014 Dec 1;9:40-51. https://doi.org/10.1016/ j.epidem.2014.09.011 PMid:25480133 PMCid:PMC4258236

105. Alenazi TH, Al Arbash H, El-Saed A, Alshamrani MM, BaffoeBonnie $\mathrm{H}$, Arabi YM, et al. Identified transmission dynamics of Middle East respiratory syndrome coronavirus infection during an outbreak: implications of an overcrowded emergency department. Clinical Infectious Diseases. 2017 Aug 15;65(4):675-9. https://doi.org/10.1093/cid/cix352 PMid:28575307 PMCid:PMC7108118
106. Eifan SA, Nour I, Hanif A, Zamzam AM, AlJohani SM. A pandemic risk assessment of Middle East respiratory syndrome coronavirus (MERS-CoV) in Saudi Arabia. Saudi journal of biological sciences. 2017 Nov 1;24(7):1631-8. https://doi.org/10.1016/j.sjbs.2017.06.001 PMid:29062261 PMCid:PMC5643837

107. Poletto C, Pelat C, Lévy-Bruhl D, Yazdanpanah Y, Boëlle P, Colizza V. Assessment of the Middle East respiratory syndrome coronavirus (MERS-CoV) epidemic in the Middle East and risk of international spread using a novel maximum likelihood analysis approach. Eurosurveillance. 2014;19(23). https://doi.org/10.2807/1560-7917.ES2014. 19.23.20824

108. Kim Y, Lee S, Chu C, Choe S, Hong S, Shin Y. The characteristics of Middle Eastern respiratory syndrome coronavirus transmission dynamics in South Korea. Osong public health and research perspectives. 2016 Feb 1;7(1):49-55. https://doi.org/10.1016/j.phrp.2016.01.001 PMid:26981343 PMCid:PMC4776270

109. Zhang XS, Pebody R, Charlett A, de Angelis D, Birrell P, Kang $H$, et al. Estimating and modelling the transmissibility of Middle East Respiratory Syndrome CoronaVirus during the 2015 outbreak in the Republic of Korea. Influenza and other respiratory viruses. 2017 Sep;11(5):434-44. https://doi.org/10.1111/irv.12467 PMid: 28703921 PMCid:PMC5598245

110. Chang HJ. Estimation of basic reproduction number of the Middle East respiratory syndrome coronavirus (MERS-CoV) during the outbreak in South Korea, 2015. Biomedical engineering online. 2017 Dec 1;16(1):79. https://doi.org/10.1186/s12938-017-0370-7 PMid:28610609 PMCid:PMC5470331

111. Xia ZQ, Zhang J, Xue YK, Sun GQ, Jin Z. Modeling the transmission of Middle East respirator syndrome corona virus in the Republic of Korea. PloS one. 2015;10(12). https://doi.org/10.1371/journal.pone.0144778 PMid:26690750 PMCid:PMC4686901

112. Middle East respiratory syndrome coronavirus (MERS-CoV) [Internet]. World Health Organization. 2020 [cited 15 April 2020]. Available at: https://www.who.int/emergencies/ mers-cov/en/

113. WHO | SARS (Severe Acute Respiratory Syndrome) [Internet]. Who.int. 2020 [cited 15 April 2020]. Available at: https://www.who.int/ith/diseases/sars/en/

114. [Internet]. Who.int. 2020 [cited 15 April 2020]. Available from: https://www.who.int/csr/sars/en/WHOconsensus. pdf

115. Lipsitch M, Cohen T, Cooper B, Robins JM, Ma S, James L, et al. Transmission dynamics and control of severe acute respiratory syndrome. Science. 2003 Jun 20;300(5627):1966-70. https://doi.org/10.1126/science. 1086616 PMid:12766207 PMCid:PMC2760158

116. WHO | Recommended procedures for prevention and management of probable cases of SARS on International Cruise Vessels [Internet]. Who.int. 2020 [cited 15 April 2020]. Available at: https://www.who.int/csr/sars/travel/ vessels/en/

117. Division U. UNSD - Methodology [Internet]. Unstats.un.org. 2020 [cited 15 April 2020]. Available at: https://unstats.un.org/unsd/methodology/m49/

118. Ebola virus disease [Internet]. Who.int. 2020 [cited 15 April 2020]. Available at: https://www.who.int/news-room/factsheets/detail/ebola-virus-disease 
119. Althaus CL. Estimating the reproduction number of Ebola virus (EBOV) during the 2014 outbreak in West Africa. PLoS currents. 2014 Sep 2;6. https://doi.org/10.1371/ currents.outbreaks.91afb5e0f279e7f29e7056095255b288

120. 2014-2016 Ebola Outbreak in West Africa | History | Ebola (Ebola Virus Disease) | CDC [Internet]. Cdc.gov. 2020 [cited 15 April 2020]. Available at: https://www.cdc.gov/vhf/ ebola/history/2014-2016-outbreak/index.html

121. COVID-19. The importance of diagnostic testing for COVID19 [Internet]. Infectious Diseases Hub. 2020 [cited 17 April 2020]. Available at: https://www.id-hub.com/2020/04/02/ the-importance-of-diagnostic-testing-for-covid-19/

122. Diseases S. COVID-19 science: Why testing is so important [Internet]. Medicalxpress.com. 2020 [cited 17 April 2020]. Available at: https://medicalxpress.com/news/2020-04covid-science-important.html

123. Correction to Lancet Glob Health 2020; published online Feb 28. The Lancet Global Health. 2020. https://doi.org/10.1016/S2214-109X(20)30074-7

124. To K, Tsang O, Yip C, Chan K, Wu T, Chan J, et al. Consistent Detection of 2019 Novel Coronavirus in Saliva. Clinical Infectious Diseases. 2020. https://doi.org/10.1093/cid/ ciaa149

125. To KK, Yip CC, Lai CY, Wong CK, Ho DT, Pang PK, et al. Saliva as a diagnostic specimen for testing respiratory virus by a point-of-care molecular assay: a diagnostic validity study. Clinical Microbiology \& Infection. 2019 Mar 1;25(3):372-8. https://doi.org/10.1016/j.cmi.2018.06.009 PMid:29906597

126. Corman VM, Landt O, Kaiser M, Molenkamp R, Meijer A, Chu DK, et al. Detection of 2019 novel coronavirus (2019-nCoV) by real-time RT-PCR. Eurosurveillance. 2020 Jan 23;25(3):2000045. https://doi.org/10.2807/1560-7917.ES. 2020.25.3.2000045

127. Li X, Geng M, Peng Y, Meng L, Lu S. Molecular immune pathogenesis and diagnosis of COVID-19. Journal of Pharmaceutical Analysis. 2020 Mar 5. https://doi.org/10.1016/j.jpha.2020.03.001

128. Xie C, Jiang L, Huang G, Pu H, Gong B, Lin H, et al. Comparison of different samples for 2019 novel coronavirus detection by nucleic acid amplification tests. International Journal of Infectious Diseases. 2020 Feb 27. https://doi.org/10.1016/j.ijid.2020.02.050 PMid:32114193 PMCid:PMC7129110

129. Yam WC, Chan KH, Poon LL, Guan Y, Yuen KY, Seto WH, Peiris JS. Evaluation of reverse transcription-PCR assays for rapid diagnosis of severe acute respiratory syndrome associated with a novel coronavirus. Journal of clinical microbiology. $2003 \quad$ Oct 1;41(10):4521-4. https://doi.org/10.1128/JCM.41.10.4521-4524.2003 PMid:14532176 PMCid:PMC254368

130. Administrator J. Global Progress on COVID-19 SerologyBased Testing [Internet]. Johns Hopkins Center for Health Security. 2020 [cited 17 April 2020]. Available at: https://www.centerforhealthsecurity.org/resources/COVI D-19/serology/Serology-based-tests-for-COVID-19.html

131. Liu W, Liu L, Kou G, Zheng Y, Ding Y, Ni W, et al. Evaluation of Nucleocapsid and Spike Protein-based ELISAs for detecting antibodies against SARS-CoV-2. Journal of Clinical Microbiology. $2020 \quad$ Mar 30. https://doi.org/10.1128/JCM.00461-20 PMid:32229605
132. Li Z, Yi Y, Luo X, Xiong N, Liu Y, Li S, et al. Development and clinical application of a rapid IgM - IgG combined antibody test for SARS - CoV - 2 infection diagnosis. Journal of medical virology. 2020 Feb 27. https://doi.org/10.1002/jmv.25727

133. Why Do We Need Antibody Tests for COVID-19 and How to Interpret Test Results [Internet]. Diazyme Laboratories. 2020 [cited 17 April 2020]. Available at: http://www.diazyme.com/covid-19-antibody-tests

134. Pan Y, Guan H, Zhou S, Wang Y, Li Q, Zhu T, et al. Initial CT findings and temporal changes in patients with the novel coronavirus pneumonia (2019-nCoV): a study of 63 patients in Wuhan, China. European Radiology. 2020. https://doi.org/10.1007/s00330-020-06731-x

135. Kanne JP. Chest CT findings in 2019 novel coronavirus (2019-nCoV) infections from Wuhan, China: key points for the radiologist. https://doi.org/10.1148/radiol.2020200 241

136. Müller NL, Ooi GC, Khong PL, Zhou LJ, Tsang KW, Nicolaou $\mathrm{S}$. High-resolution $\mathrm{CT}$ findings of severe acute respiratory syndrome at presentation and after admission. American Journal of Roentgenology. 2004 Jan;182(1):39-44. https://doi.org/10.2214/ajr.182.1.1820039 PMid:14684509

137. Das KM, Lee EY, Jawder SE, Enani MA, Singh R, Skakni L, et al. Acute Middle East respiratory syndrome coronavirus: temporal lung changes observed on the chest radiographs of 55 patients. American Journal of Roentgenology. 2015 Sep;205(3):W267-S274. https://doi.org/10.2214/AJR.15. 14445 PMid:26102309

138. Chung M, Bernheim A, Mei X, Zhang N, Huang M, Zeng X, et al. CT imaging features of 2019 novel coronavirus (2019nCoV). Radiology. 2020 Apr;295(1):202-7. https://doi.org/ 10.1148/radiol.2020200230 PMid:32017661

139. Ullah MA, Araf Y, Sarkar B, Moin AT, Reshad RAI, Rahman $\mathrm{MH}$. Pathogenesis, Diagnosis and Possible Therapeutic Options for COVID-19. Preprints 2020, 2020040372. https://doi.org/10.20944/preprints202004.0372.v1

140. Zhang JJ, Dong X, Cao YY, Yuan YD, Yang YB, Yan YQ, et al. Clinical characteristics of 140 patients infected with SARS - CoV - 2 in Wuhan, China. Allergy. 2020 Feb 19. https://doi.org/10.1111/all.14238 PMid:32077115

141. Broughton JP, Deng X, Yu G, Fasching CL, Servellita V, Singh J, et al. CRISPR-Cas12-based detection of SARSCoV-2. Nature Biotechnology. 2020 Apr 16:1-5. https://doi. org/10.1038/s41587-020-0513-4 PMid:32300245

142. Gene editing by CRISPR-Cas [Internet]. Nature.com. 2020 [cited 22 April 2020]. Available at: https://www.nature.com /articles/d42859-019-00088-y

143. Contributor A. What Is CRISPR? [Internet]. livescience.com. 2020 [cited 22 April 2020]. Available at: https://www.live science.com/58790-crispr-explained.html

144. Chen JS, Ma E, Harrington LB, Da Costa M, Tian X, Palefsky JM, Doudna JA. CRISPR-Cas12a target binding unleashes indiscriminate single-stranded DNase activity. Science. 2018 Apr 27;360(6387):436-9. https://doi.org/10.1126/ science.aar6245 PMid:29449511 PMCid:PMC6628903

145. Li SY, Cheng QX, Wang JM, Li XY, Zhang ZL, Gao S, et al. CRISPR-Cas12a-assisted nucleic acid detection. Cell discovery. 2018 Apr 24;4(1):1-4. https://doi.org/10.1038/ s41421-018-0028-z PMid:29707234 PMCid:PMC5913299 
146. Coronavirus Disease 2019 (COVID-19) [Internet]. Centers for Disease Control and Prevention. 2020 [cited 22 April 2020]. Available at: https://www.cdc.gov/coronavirus/ 2019-ncov/lab/index.html?CDC_AA_refVal=https\%3A\%2F \%2Fwww.cdc.gov\%2Fcoronavirus\%2F2019-ncov\%2Flab $\% 2$ Frt-pcr-detection-instructions.html

147. [Internet]. Who.int. 2020 [cited 22 April 2020]. Available at: https://www.who.int/docs/default-source/coronaviruse/ wuhan-virus-assay-v1991527e5122341d99287a1b17c111 902.pdf

148. [Internet]. Fda.gov. 2020 [cited 22 April 2020]. Available at: https://www.fda.gov/media/136315/download

149. Myhrvold C, Freije CA, Gootenberg JS, Abudayyeh OO, Metsky HC, Durbin AF, et al. Field-deployable viral diagnostics using CRISPR-Cas13. Science. 2018 Apr 27;360(6387):444-8. https://doi.org/10.1126/science.aas 8836 PMid:29700266 PMCid:PMC6197056

150. Zhang F, Abudayyeh OO, Gootenberg JS. A protocol for detection of COVID-19 using CRISPR diagnostics. A protocol for detection of COVID-19 using CRISPR diagnostics. 2020;8. Available at: https://go.idtdna.com/ rs/400-UEU-432/images/Zhang\%20et\%20al.\%2C\%202020 \%20COVID-19\%20detection\%20\%28updated\%29.pdf

151. Wang LS, Wang YR, Ye DW, Liu QQ. A review of the 2019 Novel Coronavirus (COVID-19) based on current evidence. International journal of antimicrobial agents. $2020 \mathrm{Mar}$ 19:105948. https://doi.org/10.1016/j.ijantimicag.2020.105 948

152. Wu D, Wu T, Liu Q, Yang Z. The SARS-CoV-2 outbreak: What we know. International Journal of Infectious Diseases. 2020;94. https://doi.org/10.1016/j.ijid.2020.03.004 PMid: 32171952 PMCid:PMC7102543

153. Al-Quteimat OM, Amer AM. SARS-CoV-2 outbreak: How can pharmacists help? Research in Social and Administrative Pharmacy. 2020. https://doi.org/10.1016/j.sapharm.2020. 03.018 PMid:32241695

154. Zumla A, Chan JFW, Azhar El, Hui DSC, Yuen K-Y. Coronaviruses - drug discovery and therapeutic options. Nature Reviews Drug Discovery. 2016Dec;15(5). https://doi.org/10.1038/nrd.2015.37 PMid:26868298 PMCid:PMC7097181

155. Jin Y-H, Cai L, Cheng Z-S, Cheng H, Deng T, Fan Y-P, et al. A rapid advice guideline for the diagnosis and treatment of 2019 novel coronavirus (2019-nCoV) infected pneumonia (standard version). Military Medical Research. 2020Jun;7(1). https://doi.org/10.1186/s40779-020-002468

156. FIP Covid-19 Information Hub [Internet]. fip. [cited 2020Apr24]. Available at: https://www.fip.org/coronavirus

157. NHS Choices. NHS; [cited 2020Apr24]. Available at: https://www.england.nhs.uk/coronavirus/publication/no vel-coronavirus-covid-19-standard-operating-procedurecommunity-health-services/

158. Lu H. Drug treatment options for the 2019-new coronavirus (2019-nCoV). BioScience Trends. 2020;14(1). https://doi.org/10.5582/bst.2020.01020 PMid:31996494

159. Wu Z, Mcgoogan JM. Characteristics of and Important Lessons From the Coronavirus Disease 2019 (COVID-19) Outbreak in China. Jama. 2020 Jul;323(13). https://doi.org/ 10.1001/jama.2020.2648 PMid:32091533
160. Kim Y, Liu H, Kankanamalage ACG, Weerasekara S, Hua DH, Groutas WC, et al. Reversal of the Progression of Fatal Coronavirus Infection in Cats by a Broad-Spectrum Coronavirus Protease Inhibitor. PLOS Pathogens. 2016;12(3). https://doi.org/10.1371/journal.ppat.1005531 PMid:27027316 PMCid:PMC4814111

161. Channappanavar R, Fett C, Mack M, Eyck PPT, Meyerholz DK, Perlman S. Sex-Based Differences in Susceptibility to Severe Acute Respiratory Syndrome Coronavirus Infection. The Journal of Immunology. 2017Mar;198(10). https://doi.org/10.4049/jimmunol.1601896 PMid:28373583 PMCid:PMC5450662

162. Vellingiri B, Jayaramayya K, lyer M, Narayanasamy A, Govindasamy V, Giridharan B, et al. COVID-19: A promising cure for the global panic. Science of The Total Environment. 2020;725. https://doi.org/10.1016/j.scitot env.2020.138277 PMid:32278175 PMCid:PMC7128376

163. Mulangu S, Dodd LE, Davey RT, Mbaya OT, Proschan M, Mukadi D, et al. A Randomized, Controlled Trial of Ebola Virus Disease Therapeutics. New England Journal of Medicine. 2019Dec;381(24). https://doi.org/10.1056/ NEJMoa1910993 PMid:31774950

164. Tchesnokov E, Feng J, Porter D, Götte M. Mechanism of Inhibition of Ebola Virus RNA-Dependent RNA Polymerase by Remdesivir. Viruses. 2019Apr;11(4). https://doi.org/ 10.3390/v11040326 PMid:30987343 PMCid:PMC6520719

165. Agostini ML, Andres EL, Sims AC, Graham RL, Sheahan TP, Lu X, et al. Coronavirus Susceptibility to the Antiviral Remdesivir (GS-5734) Is Mediated by the Viral Polymerase and the Proofreading Exoribonuclease. mBio. 2018Jun;9(2). https://doi.org/10.1128/mBio.00221-18 PMid:29511076 PMCid:PMC5844999

166. Warren TK, Jordan R, Lo MK, Ray AS, Mackman RL, Soloveva V, et al. Therapeutic efficacy of the small molecule GS-5734 against Ebola virus in rhesus monkeys. Nature. 2016 Mar;531(7594). https://doi.org/10.1038/ nature 17180

167. Arabi YM, Alothman A, Balkhy HH, Al-Dawood A, Aljohani S, Harbi SA, et al. Treatment of Middle East Respiratory Syndrome with a combination of lopinavir-ritonavir and interferon- $\beta 1 b$ (MIRACLE trial): study protocol for a randomized controlled trial. Trials. 2018;19(1). https://doi.org/10.1186/s13063-017-2427-0 PMid:29382391 PMCid:PMC5791210

168. Sheahan TP, Sims AC, Graham RL, Menachery VD, Gralinski LE, Case JB, et al. Broad-spectrum antiviral GS-5734 inhibits both epidemic and zoonotic coronaviruses. Science Translational Medicine. 2017;9(396). https://doi.org/10.1126/scitranslmed.aal3653 PMid:28659436 PMCid:PMC5567817

169. Menachery VD, Yount BL, Debbink K, Agnihothram S, Gralinski LE, Plante JA, et al. A SARS-like cluster of circulating bat coronaviruses shows potential for human emergence. Nature Medicine. 2015Sep;21(12). https://doi. org/10.1038/nm.3985 PMid:26552008 PMCid:PMC4797993

170. Brown AJ, Won JJ, Graham RL, Dinnon KH, Sims AC, Feng $J Y$, et al. Broad spectrum antiviral remdesivir inhibits human endemic and zoonotic deltacoronaviruses with a highly divergent RNA dependent RNA polymerase. Antiviral Research. 2019;169. https://doi.org/10.1016/j. antiviral.2019.104541 PMid:31233808 PMCid:PMC6699884 
171. de Wit E, Feldmann F, Cronin J, Jordan R, Okumura A, Thomas T, et al. Prophylactic and therapeutic remdesivir (GS-5734) treatment in the rhesus macaque model of MERS-CoV infection. Proceedings of the National Academy of Sciences. 2020 Mar 24;117(12). https://doi.org/10.1073/ pnas.1922083117 PMid:32054787 PMCid:PMC7104368

172. Wang M, Cao R, Zhang L, Yang X, Liu J, Xu M, et al. Remdesivir and chloroquine effectively inhibit the recently emerged novel coronavirus (2019-nCoV) in vitro. Cell Research. 2020Apr;30(3). https://doi.org/10.1038/s41422020-0282-0 PMid:32020029 PMCid:PMC7054408

173. Xiao F, Tang M, Zheng X, Liu Y, Li X, Shan H. Evidence for gastrointestinal infection of SARS-CoV-2. Gastroenterology. $\quad 2020 \quad$ Mar 3. https://doi.org/10.1101/2020.02.17.20023721

174. Stebbing J, Phelan A, Griffin I, Tucker C, Oechsle O, Smith $D$, et al. COVID-19: combining antiviral and antiinflammatory treatments. The Lancet Infectious Diseases. 2020;20(4). https://doi.org/10.1016/S1473-3099(20)301328

175. Lai C-C, Shih T-P, Ko W-C, Tang H-J, Hsueh P-R. Severe acute respiratory syndrome coronavirus 2 (SARS-CoV-2) and coronavirus disease-2019 (COVID-19): The epidemic and the challenges. International Journal of Antimicrobial Agents. 2020;55(3). https://doi.org/10.1016/j.ijantimicag. 2020.105924 PMid:32081636 PMCid:PMC7127800

176. Zhai P, Ding Y, Wu X, Long J, Zhong Y, Li Y. The epidemiology, diagnosis and treatment of COVID-19. International Journal of Antimicrobial Agents. 2020. https://doi.org/10.1016/j.ijantimicag.2020.105955 PMid:32234468 PMCid:PMC7138178

177. Falzarano D, Wit ED, Rasmussen AL, Feldmann F, Okumura $A$, Scott DP, et al. Treatment with interferon- $a 2 b$ and ribavirin improves outcome in MERS-CoV-infected rhesus macaques. Nature Medicine. 2013Aug;19(10). https://doi.org/10.1038/nm.3362 PMid:24013700 PMCid:PMC4093902

178. Elfiky AA. Anti-HCV, nucleotide inhibitors, repurposing against COVID-19. Life Sciences. 2020;248. https://doi.org/10.1016/j.lfs.2020.117477 PMid:32119961 PMCid:PMC7089605

179. Wang Z, Chen X, Lu Y, Chen F, Zhang W. Clinical characteristics and therapeutic procedure for four cases with 2019 novel coronavirus pneumonia receiving combined Chinese and Western medicine treatment. BioScience Trends. 2020;14(1). https://doi.org/10.5582/ bst.2020.01030 PMid:32037389

180. Chu CM, Cheng VC, Hung IF, Wong MM, Chan KH, Chan KS, et al. Role of lopinavir/ritonavir in the treatment of SARS: initial virological and clinical findings. Thorax. $2004 \mathrm{Mar}$ 1;59(3):252-6. https://doi.org/10.1136/thorax.2003.012658 PMid:14985565 PMCid:PMC1746980

181. Yao TT, Qian JD, Zhu WY, Wang Y, Wang GQ. A systematic review of lopinavir therapy for SARS coronavirus and MERS coronavirus - A possible reference for coronavirus disease - 19 treatment option. Journal of Medical Virology. 2020Dec;92(6). https://doi.org/10.1002/jmv. 25729 PMid:32104907

182. Wu C, Liu Y, Yang Y, Zhang P, Zhong W, Wang Y, et al. Analysis of therapeutic targets for SARS-CoV-2 and discovery of potential drugs by computational methods. Acta Pharmaceutica Sinica B. 2020. https://doi.org/10.1016/j.apsb.2020.02.008
183. Morse JS, Lalonde T, Xu S, Liu WR. Learning from the Past: Possible Urgent Prevention and Treatment Options for Severe Acute Respiratory Infections Caused by 2019 nCoV. ChemBioChem. 2020;21(5). https://doi.org/10.1002/ cbic.202000047 PMid:32022370 PMCid:PMC7162020

184. Savarino A, Di Trani L, Donatelli I, Cauda R, Cassone A. New insights into the antiviral effects of chloroquine. The Lancet infectious diseases. 2006 Feb 1;6(2):67-9. https://doi.org/10.1016/S1473-3099(06)70361-9

185. Yan Y, Zou Z, Sun Y, Li X, Xu K-F, Wei Y, et al. Anti-malaria drug chloroquine is highly effective in treating avian influenza A H5N1 virus infection in an animal model. Cell Research. 2012Apr;23(2). https://doi.org/10.1038/cr.2012. 165 PMid:23208422 PMCid:PMC3567830

186. Rolain J-M, Colson P, Raoult D. Recycling of chloroquine and its hydroxyl analogue to face bacterial, fungal and viral infections in the 21st century. International Journal of Antimicrobial Agents. 2007;30(4). https://doi.org/10.1016/j.ijantimicag.2007.05.015 PMid:17629679 PMCid:PMC7126847

187. Schrezenmeier E, Dörner T. Mechanisms of action of hydroxychloroquine and chloroquine: implications for rheumatology. Nature Reviews Rheumatology. 2020Jul;16(3). https://doi.org/10.1038/s41584-020-0372-x PMid:32034323

188. Savarino A, Boelaert JR, Cassone A, Majori G, Cauda R. Effects of chloroquine on viral infections: an old drug against todays diseases. The Lancet Infectious Diseases. 2003;3(11). https://doi.org/10.1016/S1473-3099(03)008065

189. Gao J, Tian Z, Yang X. Breakthrough: Chloroquine phosphate has shown apparent efficacy in treatment of COVID-19 associated pneumonia in clinical studies. BioScience Trends. 2020;14(1). https://doi.org/10.5582/ bst.2020.01047 PMid:32074550

190. Vincent MJ, Bergeron E, Benjannet S, Erickson BR, Rollin PE, Ksiazek TG, Seidah NG, Nichol ST. Chloroquine is a potent inhibitor of SARS coronavirus infection and spread. Virology journal. 2005 Dec 1;2(1):69. https://doi.org/10.1186/1743-422X-2-69 PMid:16115318 PMCid:PMC1232869

191. Yao X, Ye F, Zhang M, Cui C, Huang B, Niu P, et al. In Vitro Antiviral Activity and Projection of Optimized Dosing Design of Hydroxychloroquine for the Treatment of Severe Acute Respiratory Syndrome Coronavirus 2 (SARS-CoV-2). Clinical Infectious Diseases. 2020Sep. https://doi.org/ 10.1093/cid/ciaa237 PMid:32150618 PMCid:PMC7108130

192. Jie Z, He H, Xi H, Zhi Z. Multicenter Collaboration Group of Department of Science and Technology of Guangdong Province and Health Commission of Guangdong Province for Chloroquine in the Treatment of Novel Coronavirus Pneumonia. Expert Consensus on Chloroquine Phosphate for the Treatment of Novel Coronavirus Pneumonia [in Chinese]. 2020;10:1001-0939.

193. Colson P, Rolain J-M, Raoult D. Chloroquine for the 2019 novel coronavirus SARS-CoV-2. International Journal of Antimicrobial Agents. 2020;55(3). https://doi.org/10.1016/j.ijantimicag.2020.105923 PMid:32070753 PMCid:PMC7134866 
194. Mair-Jenkins J, Saavedra-Campos M, Baillie JK, Cleary P, Khaw F-M, Lim WS, et al. The Effectiveness of Convalescent Plasma and Hyperimmune Immunoglobulin for the Treatment of Severe Acute Respiratory Infections of Viral Etiology: A Systematic Review and Exploratory Metaanalysis. Journal of Infectious Diseases. 2014;211(1). https://doi.org/10.1093/infdis/jiu396 PMid:25030060 PMCid:PMC4264590

195. Cheng Y, Wong R, Soo YOY, Wong WS, Lee CK, Ng MHL, et al. Use of convalescent plasma therapy in SARS patients in Hong Kong. European Journal of Clinical Microbiology \& Infectious Diseases. 2004;24(1). https://doi.org/10.1007/ s10096-004-1271-9 PMid:15616839 PMCid:PMC7088355

196. Hung IF, To KK, Lee CK, Lee KL, Chan K, Yan WW, et al. Convalescent plasma treatment reduced mortality in patients with severe pandemic influenza A (H1N1) 2009 virus infection. Clinical Infectious Diseases. 2011 Feb 15;52(4). https://doi.org/10.1093/cid/ciq106 PMid: 21248066

197. Baron S, editor. Medical Microbiology. 4th edition. Galveston (TX): University of Texas Medical Branch at Galveston; 1996. Available at: https://www.ncbi.nlm.nih. gov/books/NBK7627/

198. Soo Y, Cheng Y, Wong R, Hui D, Lee C, Tsang K, et al. Retrospective comparison of convalescent plasma with continuing high-dose methylprednisolone treatment in SARS patients. Clinical Microbiology and Infection. 2004;10(7). https://doi.org/10.1111/j.1469-0691.2004. 00956.x PMid:15214887 PMCid:PMC7129386

199. Du L, He Y, Zhou Y, Liu S, Zheng BJ, Jiang S. The spike protein of SARS-CoV-a target for vaccine and therapeutic development. Nature Reviews Microbiology. 2009 Mar;7(3). https://doi.org/10.1038/nrmicro2090 PMid: 19198616 PMCid:PMC2750777

200. Zhang J, Zeng H, Gu J, Li H, Zheng L, Zou Q. Progress and Prospects on Vaccine Development against SARS-CoV-2. Vaccines. 2020 Jun;8(2). https://doi.org/10.3390/ vaccines 8020153 PMid:32235387

201. Agnandji ST, Huttner A, Zinser ME, Njuguna P, Dahlke C, Fernandes JF, et al. Phase 1 trials of rVSV Ebola vaccine in Africa and Europe. New England Journal of Medicine. 2016 Apr 28;374(17). Available at: https://www.nejm.org/ doi/full/10.1056/nejmoa1502924

202. Diseases TLI. Challenges of coronavirus disease 2019. The Lancet Infectious Diseases. 2020;20(3). https://doi.org/ 10.1016/S1473-3099(20)30072-4

203. Amanat F, Krammer F. SARS-CoV-2 vaccines: status report. Immunity. 2020 Apr 6. https://doi.org/10.1016/j.immuni. 2020.03.007 PMid:32259480 PMCid:PMC7136867

204. Sambhara S, Mcelhaney JE. Immunosenescence and Influenza Vaccine Efficacy. Current Topics in Microbiology and Immunology Vaccines for Pandemic Influenza. 2009. https://doi.org/10.1007/978-3-540-92165-3_20 PMid:19768417 PMCid:PMC7121450

205. Sharma A, Krause A, Worgall S. Recent developments for Pseudomonas vaccines. Human Vaccines. 2011;7(10). https://doi.org/10.4161/hv.7.10.16369 PMid:21941090 PMCid:PMC3360073

206. Le TT, Andreadakis Z, Kumar A, Román RG, Tollefsen S, Saville $M$, et al. The COVID-19 vaccine development landscape [Internet]. Nature News. Nature Publishing Group; 2020 [cited 2020Apr15]. Available at: https://www.nature.com/articles/d41573-020-00073-5
207. Pardi N, Hogan MJ, Porter FW, Weissman D. mRNA vaccines - a new era in vaccinology. Nature Reviews Drug Discovery. 2018Dec;17(4). https://doi.org/10.1038/ nrd.2017.243 PMid:29326426 PMCid:PMC5906799

208. Gonzalez-Nicolini V, Sanchez-Bustamante CD, Hartenbach $S$, Fussenegger M. Adenoviral vector platform for transduction of constitutive and regulated tricistronic or triple-transcript transgene expression in mammalian cells and microtissues. The Journal of Gene Medicine. 2006;8(10). https://doi.org/10.1002/jgm.960 PMid: 16960915

209. Azmi F, Fuaad AAHA, Skwarczynski M, Toth I. Recent progress in adjuvant discovery for peptide-based subunit vaccines. Human Vaccines \& Immunotherapeutics. 2013Mar;10(3). https://doi.org/10.4161/hv.27332 PMid: 24300669 PMCid:PMC4130256

210. Ahmed SF, Quadeer AA, Mckay MR. Preliminary identification of potential vaccine targets for the COVID-19 coronavirus (SARS-CoV-2) based on SARS-CoV immunological studies. 2020Apr. https://doi.org/10.1101/ 2020.02.03.933226

211. Liu H, Su D, Zhang J, Ge S, Li Y, Wang F, et al. Improvement of Pharmacokinetic Profile of TRAIL via Trimer-Tag Enhances its Antitumor Activity in vivo. Scientific Reports. 2017;7(1). https://doi.org/10.1038/s41598-017-09518-1 PMid:28827692 PMCid:PMC5566391

212. Takashima Y, Osaki M, Ishimaru Y, Yamaguchi H, Harada A. Artificial molecular clamp: a novel device for synthetic polymerases. Angewandte Chemie International Edition. 2011 Aug 8;50(33):7524-8. https://doi.org/10.1002/ anie.201102834

213. Walsh F. Coronavirus: First patients injected in UK vaccine trial [Internet]. BBC News. BBC; 2020 [cited 2020Apr27]. Availableat:https://www.bbc.com/news/health-52394485

214. Lane R. Sarah Gilbert: carving a path towards a COVID-19 vaccine. The Lancet. 2020;395(10232). https://doi.org/ 10.1016/S0140-6736(20)30796-0

215. Decaro N, Lorusso A. Novel human coronavirus (SARS-CoV2): a lesson from animal coronaviruses. Veterinary Microbiology. 2020 Apr 14:108693. https://doi.org/10.1016 /j.vetmic.2020.108693 PMCid:PMC7195271

216. Li H, Mendelsohn E, Zong C, Zhang W, Hagan E, Wang N, et al. Human-animal interactions and bat coronavirus spillover potential among rural residents in Southern China. Biosafety and Health. 2019 Sep 1;1(2). https://doi. org/10.1016/j.bsheal.2019.10.004 PMCid:PMC7148670

217. Aljofan M, Gaipov A. COVID-19 Treatment: The Race Against Time. Electronic Journal of General Medicine. 2020May;17(6). https://doi.org/10.29333/ejgm/7890

218. Zhao H, Wald J, Palmer M, Han Y. Hydroxychloroquineinduced cardiomyopathy and heart failure in twins. Journal of Thoracic Disease. 2018;10(1). https://doi.org/10.21037/jtd.2017.12.66 PMid:29600108 PMCid:PMC5863196

219. Sebba A. Tocilizumab: The first interleukin-6-receptor inhibitor. American Journal of Health-System Pharmacy. 2008Jan;65(15). https://doi.org/10.2146/ajhp070449 PMid:18653811

220. Shimabukuro-Vornhagen A, Gödel $P$, Subklewe $M$, Stemmler HJ, Schlößer HA, Schlaak M, et al. Cytokine release syndrome. Journal for ImmunoTherapy of Cancer. 2018;6(1). https://doi.org/10.1186/s40425-018-0343-9 PMid:29907163 PMCid:PMC6003181 
221. Russell CD, Millar JE, Baillie JK. Clinical evidence does not support corticosteroid treatment for 2019-nCoV lung injury. The Lancet. 2020;395(10223). https://doi.org/ 10.1016/S0140-6736(20)30317-2

222. Chinese Clinical Trial Register (ChiCTR) - The world health organization international clinical trials registered organization registered platform. [cited 2020May6]. Available at: http://www.chictr.org.cn/showprojen.aspx? proj=49409

223. Sharquie IK. BCG is a Good Immunotherapeutic Agent for Viral and Autoimmune Diseases: Is it a New Weapon against Coronavirus (COVID-19)? Electronic Journal of General Medicine. 2020Jun;17(6). https://doi.org/10.29333 /ejgm/7892

224. Coronavirus FAQ's by Dr. Megan ... - Abundance Foundation [Internet]. [cited 2020May6]. Available at: https://www.abundance.org/coronavirus-faqs-by-drmegan-murray-harvard-infectious-disease-specialist/

225. Singh R, Mahajan B, Dhawan M. Herpes genitalis - Topical zinc sulfate: An alternative therapeutic and modality. Indian Journal of Sexually Transmitted Diseases and AIDS. 2013;34(1). ttps://doi.org/10.4103/0253-7184.112867 PMid:23919052 PMCid:PMC3730471
226. Al-Gurairi F, Al-Waiz M, Sharquie K. Oral zinc sulphate in the treatment of recalcitrant viral warts: randomized placebo-controlled clinical trial. British Journal of Dermatology. 2002;146(3). https://doi.org/10.1046/j.13652133.2002.04617.x PMid:11952542

227. Sharquie KE, Noaimi AA, Al-Salam WS. Treatment of Acute Cutaneous Leishmaniasis by Oral Zinc Sulfate and Oral Ketocanazole Singly and in Combination. Journal of Cosmetics, Dermatological Sciences and Applications. 2016;06(03). https://doi.org/10.4236/jcdsa.2016.63014

228. Sharquie KE, Najim RA, Al-Dori WS, Al-Hayani RK. Oral zinc sulfate in the treatment of Behcets disease: A double blind cross-over study. The Journal of Dermatology. 2006Jan;33(8). https://doi.org/10.1111/j.1346-8138.2006. 00128.x PMid:16923135

229. Sharquie KE. Oral Zinc Sulphate in Treatment of Alopecia Areata (Double Blind; Cross-Over Study). Journal of Clinical \& Experimental Dermatology Research. 2014;3(3). https://doi.org/10.4172/2155-9554.1000150 